\title{
Afetos e memórias em mosaico: A Associação Brasileira de História das Religiões (ABHR) em sua regionalização e internacionalização (2013 a 2015)
}

\author{
Eduardo Meinberg de Albuquerque Maranhão $F^{\circ} .{ }^{1}$
}

\section{RESUMO}

Apresento aqui algumas sensíveis memórias pessoais sobre aspectos que (des)envolveram a regionalização e a internacionalização da Associação Brasileira de História das Religiões (ABHR), ocorrida entre 2013 e 2019. Neste texto abordarei os dois primeiros anos da internacionalização e regionalização da Associação, de 2013 a 2015. Este texto é seguido por outro, publicado na Revista Plura (Dossiê 20 Anos da ABHR), e que deve ser lido na sequência a este: Memórias sensíveis em caleidoscópio: A internacionalização e a regionalização da Associação Brasileira de História das Religiões (ABHR) entre 2016 e 2019. As vivências descritas se relacionam com minha experiência na coordenação de simpósios e na Presidência desta importante entidade de estudos de religiões e religiosidades que em 20 anos - de sua gênese em 1999 até 2019 -, procurou estimular uma educação respeitosa à diversidade religiosa e a todas as formas de diversidade.

Palavras-chave: Associação Brasileira de História das Religiões (ABHR); História das Religiões e Religiosidades; Estudos das Religiões; Ciência(s) da(s) Religião(ões); diversidade religiosa

1 Presidência da Associação Internacional de Estudos de Afetos e Religiões (AMAR). Ex-Presidência da Associação Brasileira de História das Religiões (ABHR - gestões 2015-2017 e 2017-início de 2019). Docente-visitante do Programa de Pós-Graduação em Direitos Humanos, Cidadania e Políticas Públicas (PPGDH / UFPB) e do Departamento e Centro de Ciências Jurídicas da Universidade Federal da Paraíba (DCJ / CCJ / UFPB). Pós-Doutorado em Ciências das Religiões pela Universidade Federal da Paraíba (UFPB); Pós-Doutorado Interdisciplinar em Ciências Humanas pela Universidade Federal de Santa Catarina (UFSC) e Pós-Doutorado em História pela Universidade Federal de Santa Catarina (UFSC). Doutorado em História Social pela Universidade de São Paulo (USP). Mestrado em História do Tempo Presente pela Universidade do Estado de Santa Catarina (UDESC). E-mail: edumeinberg@gmail.com 


\title{
Affects and memories in mosaic: The Brazilian Association for History of Religions (ABHR) in its regionalization and internatio- nalization (2013 to 2015)
}

\begin{abstract}
I present here some sensitive personal memories about aspects that (dis) involved the regionalization and internationalization of the Brazilian Association of History of Religions (ABHR), which occurred between 2013 and 2019. In this text I will address the first two years of the internationalization and regionalization of the Association, of 2013 to 2015. This text is followed by another, published in Revista Plura (Dossier 20 Years of ABHR), which should be read following this: Sensitive memories in $\mathrm{ka}$ leidoscope: The internationalization and regionalization of the Brazilian Association of History of Religions (ABHR) between 2016 and 2019. The experiences described are related to my experience in the coordination of symposia and in the Presidency of this important entity of studies of religions and religiosities that in 20 years - from its genesis in 1999 until 2019 -, sought to stimulate an education respectful of religious diversity and all forms of diversity.
\end{abstract}

Keywords: Brazilian Association for History of Religions (ABHR); History of Religions and Religiosities; Studies of Religions; Science(s) of Religion(s); religious diversity

(...) está numa brisa chuvosa, num cheiro de quarto fechado, ou no de um primeiro fogaréu, em toda parte onde encontramos de nós mesmos o que nossa inteligência rejeitara, por julgá-lo inútil, a última reserva do passado, a melhor, aquela que, quando todas as nossas lágrimas parecem ter secado, sabe ainda fazer-nos chorar.

Michel Proust

\section{Introdução ${ }^{2}$}

"Abrindo os trabalhos" deste texto, realço a importância da leitura de outro artigo que o complementa, intitulado Memórias sensíveis em

2 Agradeço ao colega Diego Omar da Silveira (UEA) pelo gentil convite a encaminhar texto sobre minhas memórias acerca da ABHR, e elogio o mesmo por sua trajetória na Associação, especialmente durante a gestão 2015-2017, quando encabeçou a realização do primeiro (e pioneiro) Simpósio Norte da Associação, tendo como mote as religiões e religiosidades da Amazônia. Foi uma honra para mim participar da construção deste evento histórico. Recordo igualmente ter proposto à Comissão de Redação da PLURA, em maio de 2018, um dossiê sobre a História da ABHR, e fico alegre que o mesmo tenha sido elaborado e esteja no ar em breve. 
caleidoscópio: A internacionalização e a regionalização da Associação Brasileira de História das Religiões (ABHR) entre 2016 e 2019, publicado na Revista Plura (Dossiê 20 Anos da ABHR).

Apresento no presente artigo um breve caleidoscópio mnemônico e afetivo envolvendo algumas de minhas experiências na Associação Brasileira de História das Religiões (ABHR). Antes de tudo, é necessário que eu agradeça de coração a todas as pessoas com quem convivi durante minha trajetória na ABHR, acrescentando positivamente em minha vida de uma miríade de formas. A vocês, eu agradeço.

Seguido a isto, devo pedir desculpas caso eu esqueça de mencionar pessoas e episódios muito relevantes - e esquecerei, visto que faz parte da memória ser seletiva, fragmentada e "esquecida", como notava de algum modo Michel Proust, para quem a memória, por ser involuntária, é desorganizada, descontínua e fragmentária, o que conduz a um discurso igualmente desorganizado, descontínuo, fragmentário (PROUST, 2002).

Importante realçar: não tenho a ambiciosa intenção - ainda que adoraria tê-lo feito - de esboçar, como o título talvez aponte, um amplificado "mosaico de memórias sensíveis" da ABHR - certamente seria uma missão inglória tentar fazê-lo. Procurarei fazer a superficial tessitura (de modo rasurável, despretensioso e ensaístico) de algumas das minhas vivências durante minha passagem pela ABHR, na certeza de que ao ensaiarmos sobre nossas experiências ensaiamos sobre seus contextos (e de igual forma, ao ensaiarmos sobre os contextos que nos cercam, ensaiamos a nós mesmes) $)^{3}$, e que escrevendo sobre o que vivemos delineamos grades de análise e inteligibilidade acerca de nós e de nosso entorno - semelhantemente ao que já ensinava Jorge Larrosa, de que a pessoa ensaísta não põe a si mesma na escrita, mas "tira algo de si e faz algo consigo mesmo escrevendo, pensando, ensaiando" (LARROSA, 2004, p. 37). Ensaiar a mim mesme e ao contexto que me cerca (a ABHR, no caso), sinaliza para o que notava Arnaldo Huff Júnior, de que "fazer história do tempo presente começa pela definição de um problema de pesquisa que tem implicações existenciais para o

3 Utilizo linguagem neutra / não-binária de gênero ("e" ou " $\mathrm{x}$ " substituindo artigos feminino ["a"] e masculino ["o"]) durante o texto. Da mesma forma, ao falar de mim (que me defino como pessoa não-binária de gênero), utilizo do mesmo recurso. 
pesquisador" (HUFF JÚNIOR, 2009, p. 20): é certo que falar da ABHR enquanto estive por lá é também falar um pouquinho de mim.

Estou consciente de que "nem sempre a história consegue acreditar na memória, e a memória desconfia de uma reconstituição que não coloque em seu centro os direitos da lembrança (direitos de vida, de justiça, de subjetividade)" (SARLO, 2007, p. 9), e convoco/evoco aqui, justamente, meus direitos de lembrança afetiva e sensível - incluindo sabores e dissabores, afetos e desafetos, alegrias e choros (aliás, acolherei neste texto tanto choros tristes como alegres) $)^{4}$.

Sabemos igualmente (quem me lê e eu que escrevo) que registrar lembranças é fazer história. Se para Maurice Halbwachs a memória é algo natural, desinteressado e espontâneo que preserva do passado apenas aquilo que é útil enquanto elo entre este e o presente, ao tempo em que a História seria um processo político e interessado (interesseiro, talvez?), subentendida a manipulação da memória durante o processo narrativo (HALBWACHS, 1990); para Pierre Nora a memória dispõe a lembrança em um "plano sagrado", possuindo elementos afetivos, ao passo que a História "dessacraliza" a memória por ser per si problematizadora e crítica. (NORA, 1993). Das discussões sobre memória e História, algo é certo: registrar o vivido e o lembrado produz fontes para o conhecimento historiográfico e conhecer a História é compreender melhor a vida (inclusive a nossa).

Este texto é um trabalho (ou melhor, um ensaio) de História do Tempo Presente (HTP), que é definido por Jean-Pierre Rioux assim: "um vibrato do inacabado que anima todo um passado, um presente aliviado de seu autismo, uma inteligibilidade perseguida fora de alamedas percorridas, é um pouco isto, a História do Tempo Presente." (RIOUX, 1999, p. 50). Ensejo que a partir de algumas dessas alamedas percorridas aprendamos acerca das mesmas e, especialmente, da gente, e prossigamos em caminhos que sejam profundamente abençoado(re) $\mathrm{s}$ e proveitosos. E os primeiros passos de minha história com a ABHR

4 Vale realçar que, destarte uma miríade de contribuições de diversas pessoas associadas em todos estes anos, colaborações estas que são merecedoras dos maiores aplausos, este esforço memorialístico incide sobre momentos que vivenciei particularmente, bem como atividades que sugeri e coloquei em prática - geralmente com a atuação de boas companheiras e bons companheiros. 
se relacionam com um pontapé inicial, ou de alguma forma, com um choro inicial. Mas antes de comentar sobre isto, talvez seja necessário explicar um pouco o que é a ABHR.

\section{$\mathbf{A} \mathbf{A B H R}^{5}$}

A Associação Brasileira de História das Religiões (ABHR) foi fundada em 25 de junho de 1999 (às 18h), durante Assembleia Geral que seguiu o Edital de Convocação da programação do I Simpósio sobre História das Religiões, realizado na Faculdade de Ciências e Letras da Universidade Estadual Paulista Júlio de Mesquita Filho (UNESP) de Assis, São Paulo, por docentes da linha de pesquisa Religiões e Visões de Mundo, do Programa de Pós-Graduação em História da Faculdade de Ciências e Letras desta universidade. ${ }^{6}$

Entretanto, apesar do nome "História das Religiões", a ABHR traz em seu bojo um caráter híbrido em termos disciplinares, como apontava Elizete da Silva, para quem a Associação trazia "desde o inicio uma perspectiva interdisciplinar, congregando antropólogos, sociólogos, filósofos, psicólogos e historiadores, enlaçados pelo desejo de estudar grupos religiosos." (SILVA, 2020). No mesmo sentido, para Wellington Teodoro da Silva,

a trajetória da ABHR é marcada pela não diretividade de um ou outro recorte disciplinar. É razoável pensar que essa característica deita raiz no seu núcleo fundante. Os professores da linha de pesquisa

5 Este intróito retoma parte do texto de apresentação da Associação publicado no seu site oficial www.abhr.org.br, sendo de minha autoria. Este site permaneceu ativo até o final da gestão 2017-2019. Após a mesma, o mesmo foi invadido e teve parte de seu conteúdo alterado.

6 Esta primeira Assembleia Geral da ABHR, realizada no auditório Antonio Merisse, teve uma mesa composta pelos professores Eduardo Basto de Albuquerque, Benedito Miguel Angelo Perrini Gil, Ivan Esperança Rocha, Célia Carvalho de Ferreira Penço, Sidinei Galli e Milton Carlos Costa - que faziam parte da Comissão Organizadora do simpósio. Por unanimidade, a mesa sugeriu que a condução e presidência da Assembleia fosse feita por Benedito Miguel Gil, que propôs a seguinte pauta: Apresentação das pessoas presentes; informações de interesse à ABHR; eleição de Comissão para elaborar anteprojeto de Estatuto da ABHR; eleição de Comissão encarregada de dirigir a ABHR até a próxima Assembleia Geral, a ser realizada durante o II Simpósio sobre História das Religiões; escolha de data e local do II Simpósio sobre História das Religiões. Informações constantes das Atas das Assembleias da ABHR. (www.abhr.org.br). 
"Religiões e visões de mundo", do Programa de Pós-graduação em História da Unesp, campus de Assis, convocaram o Simpósio Nacional de História das Religiões que foi o evento fundador da associação. O trânsito em diferentes áreas feitos durante o período de formação desses professores pode ter contribuído para a formação da sua matriz de não diretividade disciplinar. Embora sendo todos de uma linha de pesquisa de um programa de pós-graduação, as áreas percorridas por três desses colegas, graduação, mestrado e doutorado, são: filosofia, ciências bíblicas, história, ciência política, antropologia e direito. Esse trânsito entre disciplinas seguramente influiu nos primeiros movimentos da ABHR que, seguramente, foi idealizada antes do simpósio que a fundou. Além desses colegas, a presença de pessoas de áreas diversas, no simpósio em Assis e no seguinte em Mariana, vale o destaque para a teologia e as ciências das religiões, contribuíram para o não direcionamento em uma ou outra disciplina. (SILVA, 2013, p. 16).

A ABHR é filiada, desde 2000, à International Association for History of Religions (IAHR), e se coloca aberta à criação e manutenção de diálogos, vínculos e parcerias, em regime de colaboração mútua, com outras entidades, organizações, instituições e núcleos de estudos acadêmicos de religiões e religiosidades, em níveis regional, nacional e internacional.

A ABHR é uma entidade sem fins lucrativos, não confessional / não devocional / não proselitista e apartidária, completamente independente de partidos políticos ou grupos religiosos, e que tem como objetivos: estimular a pesquisa, o ensino e a extensão universitária no campo das religiões e religiosidades e em todos os níveis acadêmicos; promover e democratizar o intercâmbio de conhecimentos acadêmicos sobre religiões e religiosidades através de encontros científicos em níveis regional, nacional e internacional; incentivar publicações acadêmica e socialmente relevantes das pessoas associadas; e contribuir para o alargamento, consolidação e refino dos estudos que têm as religiosidades e religiões como mote.

A ABHR promove intercâmbios entre pesquisadoras/es de quaisquer áreas, e não somente entre historiadoras/es, e por esta razão é conhecida como uma associação de estudos de religiões e religiosidades: grande parte das pessoas associadas são provenientes da Antropologia, Sociologia, Ciência(s) da(s) Religião(ões), Letras, Psicologia, Direito, 
Ciência Política, Teologia e outros campos, além, claro, da própria História.

Como já observava Celso Luis Terzetti Filho, "desde que foi criada, em 1999, a Associação Brasileira de História das Religiões (ABHR) tem como principal objetivo contribuir para o desenvolvimento de um campo de estudos científico sobre a religião", e "nascida da iniciativa de historiadores, logo a ABHR passou a ter em seu quadro pesquisadores de outras áreas." (TERZETTI FILHO, 2013, p. 193). No mesmo sentido, Wellington da Silva já fazia notar que a ABHR é uma entidade amplificada, cujo "percurso está acontecendo, até o momento, sem privilégios voluntários de uma ou outra área do conhecimento", o que já "deu vaga para a proposta de mudar o nome para ABER Associação Brasileira de Estudos da Religião". Para o mesmo, tal

mudança pode ser adequada porque a palavra História pode levar à falsa compreensão de haver orientação organizativa e intelectual que parta dessa área do conhecimento. Isso gera embaraços entre colegas de outras áreas que embora participem dos eventos não se sentem a vontade para permanecer de maneira orgânica como quadros da gestão dessa associação. (SILVA, 2013, p. 9).

A ABHR é composta por uma Diretoria Geral, à qual pertencem a Diretoria Executiva, formada por Presidência, Secretaria Geral, Secretaria de Divulgação e Tesouraria, bem como Coordenações Regionais. Além da Diretoria Geral, a Associação é constituída por Conselho Científico, Comissão de Redação da Plura (Revista de Estudos de Religião da ABHR), Comissão Editorial, Conselho Fiscal, Pessoas Associadas, e Assembleia Geral.

Trata-se de uma entidade que repudia qualquer tipo de discriminação, intolerância e violência, de caráter religioso ou não, e se manifesta contrária a qualquer demonstração de violação dos direitos constitucionais brasileiros, se amparando no Artigo 5o do 1o Capítulo (Título 2 - Dos Direitos e Garantias Fundamentais) da Constituição da República Federativa do Brasil, que rege:

Todos são iguais perante a lei, sem distinção de qualquer natureza, garantindo-se aos brasileiros e aos estrangeiros residentes no País a inviolabilidade do direito à vida, à liberdade, à igualdade, à segurança e 
à propriedade, nos termos seguintes: VI - é inviolável a liberdade de consciência e de crença, sendo assegurado o livre exercício dos cultos religiosos e garantida, na forma da lei, a proteção aos locais de culto e a suas liturgias (CONSTITUIÇÃO DA REPÚBLICA FEDERATIVA BRASILEIRA, 1988).

Destacou-se - de sua gênese em 1999 até o final da gestão 20172019 - o posicionamento da ABHR favorável não somente aos direitos constitucionais, mas aos Direitos Humanos em sua forma mais ampla. Como entidade que buscou promover, da maneira mais democrática possível, o alargamento e aprofundamento de intercâmbios entre pessoas que pesquisam religiosidades, religiões, espiritualidades, ateísmos e agnosticismos, a ABHR investiu em seu processo de regionalização através das Coordenações e Simpósios Regionais (realizados desde 2013), em seu processo de internacionalização, potencializado em 2013 pelo início dos Simpósios Internacionais, e em seu processo de midiatização via internet. Explicado isso, podemos voltar ao ponto anterior, relativo às minhas primeiras memórias na (e com a) ABHR.

\section{1/2012 ou o meu primeiro choro na ABHR}

A gênese das minhas memórias sobre a ABHR está em 2011. Neste ano a minha dissertação de mestrado sobre a Bola de Neve Church completava um ano de idade $^{7}$ e no doutorado eu pesquisava sobre os impactos de discursos evangélicos na construção subjetiva de pessoas transgêneras, ou o que as pessoas trans* faziam com o que determinadas instituições evangélicas procuravam fazer delas (ou com elas). ${ }^{8}$

7 Escrevi sobre as re(l)ações entre gênero, política, canção, marketing e mídia (especialmente a internet) na Bola de Neve Church, igreja de características majoritariamente neopentecostais. A dissertação foi defendida em fevereiro de 2010 no Programa de Pós-graduação em História do Tempo Presente da Universidade do Estado de Santa Catarina (PPGH/UDESC), sob a magistral orientação e coorientação de, respectivamente, Márcia Ramos de Oliveira (UDESC) e Artur Cesar Isaia (UFSC). Agradeço sobremaneira a Márcia e a Artur pelos momentos de troca sensível e apoio sempre carinhosamente dispensados a mim.

8 Pesquisei as autodenominadas igrejas cristãs inclusivas à diversidade sexual e de gênero, bem como as missões e ministérios evangélicos que se ocupavam da suposta "cura, restauração e libertação" de pessoas transgêneras e de pessoas não-hétero. A tese foi depositada em 2014 e defendida na sexta-feira 13 de maio de 2015 no Programa de Pós-Graduação em História Social da Universidade de São Paulo (PPGH/USP), contando com a preciosa orientação de José Carlos Sebe Bom Meihy, "pai” da História Oral no Brasil, a quem muito agradeço pelo respeito comigo. 
Foi neste ano que conversei pela primeira vez com Wellington Teodoro da Silva, que foi Secretário Geral (gestões 2006-20099 e 20092011) e Presidente da ABHR (gestões 2011-2013 e 2013-2015). Meu primeiro contato com o mesmo foi através de um texto seu disposto na Revista Brasileira de História das Religiões (RBHR),${ }^{10}$ da Associação Nacional de Professores de História (ANPUH). ${ }^{11}$ Como em 2011 eu estava organizando um dossiê sobre religiões e religiosidades para a História Agora $^{12}$ e havia tido contato com o interessante texto de Wellington, o convidei para que encaminhasse um artigo para integrar tal coletânea. O mesmo acolheu bem a ideia e encaminhou um artigo sobre a Nova Era, chamado "A sacralização impessoante". A partir destes momentos de diálogo soube da existência da ABHR e comentei ter interesse em conhecê-la, ao que Wellington reforçou: "espero que você possa participar de maneira ativa e orgânica". ${ }^{13}$

Recebendo divulgação do XII Simpósio Nacional da ABHR, realizado na Universidade Federal de Juiz de Fora (UFJF) em 2011 com o mote Experiências e interpretações do Sagrado: interfaces entre saberes acadêmicos e religiosos, ${ }^{14}$ encaminhei proposta de Grupo de Trabalho (GT) e Minicurso sobre as relações entre marketing, internet e espetáculo no (neo)pentecostalismo. Foi o primeiro simpósio da ABHR que eu participei e a experiência foi valiosa. A intenção de atuar no combate à intolerância religiosa através de estudos acadêmicos - o que também se presentificava no GTHRR / ANPUH - foi algo que me chamou a

9 Na gestão 2006-2009 Wellington substituiu Angelo Adriano Faria de Assis (UFV).

10 O texto era "Diálogo por cima dos muros e as Encíclicas de João XXIII e o desenvolvimentismo católico brasileiro", publicado no oitavo número da RBHR (v. 3 n. 8 (3): RBHR (Setembro/2010).

11 À época eu fazia parte como membro do Grupo de Trabalho História das Religiões e Religiosidades (GTHRR) da ANPUH e colaborava como editorx de algumas revistas acadêmicas: Oralidades - Revista de História Oral da USP, Angelus Novus - Revista dos Alunos de Pós-graduação em História da USP, e História Agora - Revista de História do Tempo Presente (revista independente e já extinta). Um pouco à posteriori (2012) também co-editei a própria RBHR, sendo na época também responsável pela criação e gerenciamento das páginas do GTHRR e da RBHR no Facebook.

12 Entre 2008 e 2014 coordenei ou co-organizei diversos dossiês não somente para as revistas mencionadas como para outras às quais me convidavam para colaborar desta forma - quase todos os dossiês se relacionando aos estudos de religiões e religiosidades; gênero e sexualidade; História do Tempo Presente e História Oral.

13 Comunicação por e-mail (17 jan. 2011).

14 O evento foi realizado entre os dias 31 de maio e 3 de junho de 2011 e organizado pelo Programa de Pós-graduação em Ciência da Religião (PPCIR) da UFJF em parceria com a ABHR. 
atenção. Em uma entrevista sobre este simpósio Arnaldo Huff Junior, coordenador do evento, declarou: "as religiões e a fé religiosa impulsionam as pessoas em direção à vida. Elas fazem coisas, ou deixam de fazer, por questões religiosas." Perguntado sobre a onda de violência em cenário internacional, ressaltou: "talvez mais do que nunca seja importante pensarmos e discutirmos a religião.” (HUFF JUNIOR, 2011).

Passeando com Arnaldo em seu fusca por Juiz de Fora (salvo engano ele me dava uma carona até o lugar onde eu me hospedava), recebi o convite para auxiliar como uma das pessoas editoras da Plura - Revista de Estudos de Religião da ABHR, juntamente com Ismael Vasconcellos (seu orientando à época) e ele mesmo. Foi um convite emocionante! eu poderia ajudar em um periódico muito bem reconhecido pela academia! ${ }^{15}$

Colaborei na consolidação da revista durante 2011 e 2013 de alguns formas: participando de reuniões como o Fórum de Editores da Sociedade de Teologia e Ciência da Religião (SOTER) e o Fórum de Editores da Associação Nacional de Pós-graduação e Pesquisa em Teologia e Ciências da Religião (ANPTECRE); participando de curso de implantação do Sistema de Editoração Eletrônica de Revistas (SEER/ IBICT); atuando no processo editorial de diversos dossiês através do SEER (encaminhamento de solicitações de parecer, recebimento das avaliações, etc); fazendo convites para publicações no periódico; e criando / gerenciando a página e grupo de Facebook da PLURA, canais de divulgação da mesma - e espero ter contribuído consistente e positivamente com a mesma durante este breve período. Minha primeira experiência na ABHR, como vimos, foi marcada por generosos convites de Wellington e Arnaldo: "participe de forma orgânica", "venha ajudar na PLURA". E agradecendo honradamente ambos os convites, aceitei.

Em 2012 participei da décima-terceira edição do Simpósio Nacional da Associação, Religião, carisma e poder: As formas da vida religiosa no Brasil. ${ }^{16}$ Durante o evento coordenei Grupo de Trabalho e ministrei Minicurso, à exemplo do ano anterior, sobre mídia e (neo)pentecostalismo. Lá, recebi novo convite da ABHR, desta vez para coordenar o primeiro Simpósio Sudeste da ABHR, a ser realizado em 2013 na Universidade de São Paulo (USP), com o tema que eu selecionasse. Aceitei o novo desafio com felicidade e retornando a São Paulo iniciei os primeiros

15 Posteriormente, Fabio Py juntou-se à equipe, trazendo ainda mais qualidade à Plura.

16 O simpósio ocorreu na Universidade Federal do Maranhão (UFMA) entre 29 de maio a 01 de junho de 2012. 
preparativos para que isto se realizasse. Um professor da Pontifícia Universidade Católica de Minas Gerais (PUC Minas) se dispôs a colaborar na coordenação do evento fazendo os pedidos de financiamento - coisa que como doutorande eu não poderia fazer. Entretanto, infelizmente o mesmo não pôde fazê-lo. Já tínhamos um site aberto para inscrições e um tema, Diversidades e (In)Tolerâncias Religiosas, e eu percebi que o evento poderia estar literalmente "indo por água abaixo".

$\mathrm{Na}$ época eu residia em Florianópolis (SC), e Wellington (na Presidência, naquele momento) em Belo Horizonte (MG), assim como Daniel Rocha, gentil Secretário de Divulgação da Associação. Conversei com ambos através da internet, e, angustiade, em ambas as conversas eu chorei - esse foi, como recordo, os primeiros dos meus choros durante minha vivência na ABHR. Demonstrando minha tristeza e preocupação em relação ao (não) andamento da organização do evento, e como eu estava me sentindo perdide, tanto Wellington quanto Daniel ratificaram a confiança em mim para coordenar o evento e me estimularam a seguir adiante - e eu prossegui. ${ }^{17}$

Naquele momento, ainda sozinhe na organização do evento, comecei a "correr atrás" de financiamentos. Consegui auxílios substanciais ao evento, vindos, por exemplo, da Faculdade Messiânica, Faculdade de Teologia Umbandista, Universidade Presbiteriana Mackenzie, Korin Alimentos Orgânicos (espero não ter esquecido de ninguém! e perdoem caso tenha feito), conseguindo mais de 600 bolsas de pano com logomarca, duas mil canetas azuis e vermelhas, mil pastas e bloquinhos, arte para o evento, ${ }^{18}$ coquetel orgânico para todas as noites, café orgânico e água mineral à vontade durante todo o dia, dentre outras coisas que não recordo. Aliás, como bem lembrado por Terzetti Filho,

Os anais e resumos do evento foram disponibilizados em CD e em formato pdf para download; os cadernos de resumo, além de estarem disponíveis nos formatos citados, também tiveram publicação impressa em livro com 435 páginas. Os financiamentos dos materiais foram conseguidos pela organização geral do evento e por Eduardo Meinberg Maranhão, que buscou apoio junto a outras instituições. Foram distribuídos kits

17 Aliás, só tenho a agradecer a ambos, e também a Ítalo Domingos Santirocchi, tesoureiro à época, por todo o apoio e carinho sempre dispensados a mim. A Direção Executiva da época contava também com Vasni de Almeida no cargo de secretário geral, mas não tive o prazer de conhecê-lo à época.

18 Elaborada gentilmente por Alexandra Abdala, da Arché Editora, e constante nas bolsas, CDs, capa dos Anais e do Caderno de Programação e Resumos do evento. 
aos inscritos. Assim, o Simpósio recebeu sacolinhas da FTU, canetas da Editora do Mackenzie, CDs da Faculdade Messiânica, subsídio do Caderno de Programação e Resumos impresso e livro com conferência e mesas da Fonte Editorial, coquetéis orgânicos da Korin e apoio financeiro do GREPO (PUC-SP). Também recebeu apoio institucional do PPG Metodista, grupo de pesquisas Mandrágora (Metodista) e da Comissão de Liberdade Religiosa da OAB. (TERZETTI FILHO, 2013, p. 195).

Importa realçar que a Fonte Editorial subsidiou o Caderno de Programação e Resumos em formato livro, e realizou a publicação e impressão do primeiro e o segundo volumes do livro do evento, organizados por mim - com o título Religiões e religiosidades em (con)textos. ${ }^{19}$

Imagem: Primeiro e segundo volumes do livro do evento ${ }^{20}$

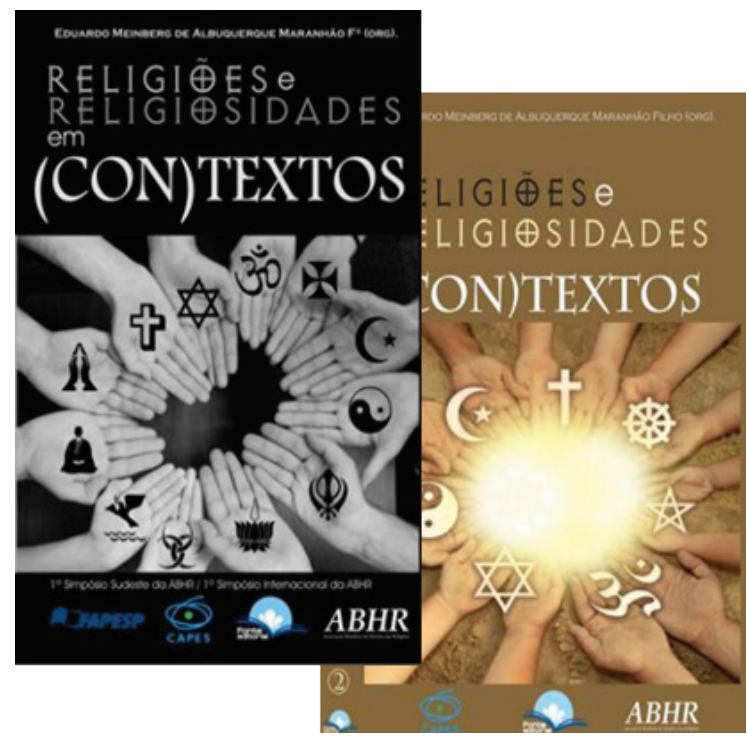

Fonte: Arquivo pessoal

19 O acerto com a editora foi o de cessão de direitos autorais destas obras diretamente à ABHR (a Associação receberia em livros o equivalente a 10\% das vendas). Entretanto, infelizmente a editora ainda não fez a cessão de tais exemplares à ABHR (recebemos apenas alguns exemplares neste simpósio de 2013 e outros no Nacional de 2015).

20 O segundo volume foi lançado em 2014. Também foi relançado em 15 de abril de 2015, na UFJF, durante o Simpósio Nacional da ABHR. A coletânea, que organizei e foi produzida pela Fonte Editorial, trouxe textos de Christina Vital da Cunha, Maria José Fontellas Rosado-Nunes, Sandra Duarte de Souza, Maria Helena Villas Bôas Concone, Karla Denise Martins, Wellington Teodoro da Silva, Frei Carlos Josaphat, Jorge Miklos, Silas Guerriero, Dilip Loundo, Peter Robert Demant, Carlos Andrade Rivas Gutierrez e Vagner Aparecido Marques. 
Em tempo e a fim de trazer um breve contexto acerca da produção bibliográfica da ABHR, vale comentar que até 2011 a produção bibliográfica da ABHR estava sob a incumbência da Editora Paulinas, especialmente de sua Coleção Estudos da ABHR, que publicou em forma impressa os textos de pessoas que participaram das Mesas Redondas e Conferências dos Simpósios Nacionais até então realizados. Como já notava Elizete da Silva,

\begin{abstract}
Além de criar condições para o debate acadêmico sobre os fenômenos do sagrado, a Associação Brasileira de História das Religiões (ABHR) passou a divulgar a produção de pesquisadores, resultantes de conferências e comunicações de seus simpósios, com publicações periódicas junto a Editora Paulinas (SILVA, 2020).
\end{abstract}

Segundo Wellington da Silva (em artigo de 2013), "até o momento foram publicados nove volumes" sendo que "esses livros oferecem boas possibilidades para uma compreensão dos estudos das religiões no Brasil no período. Outra possibilidade de compreender esse campo seria a análise dos anais dos simpósios nacionais e regionais" bem como dos grupos de trabalho que funcionam nos eventos, igualmente belas fontes para o estudo do campo das religiões e religiosidades (SILVA, 2013, p. 15). Lamentavelmente, a Paulinas foi procurada em diversos momentos a partir de 2013 para a continuidade da publicação da produção bibliográfica impressa da ABHR, mas referiu não ter mais interesse em fazê-lo dadas dificuldades financeiras. Outras editoras foram procuradas, como a Paulus e a Vozes (dentre outras), mas todas repetiam o argumento das Paulinas: "o mercado editorial já não se interessa em publicar coletâneas de simpósios pois há pouco retorno financeiro. Só há interesse em coletâneas temáticas, e as coletâneas de eventos (referentes a mesas redondas e conferências) trazem assuntos que muitas vezes não se relacionam uns com os outros". Silas Guerriero (que coordenou durante anos a Coleção Estudos da ABHR) recebeu emails da Paulinas (que Silas direcionou à Diretoria Executiva da ABHR) demonstrando a diminuição do interesse na produção dos livros que até então a editora produzia com excelência. ${ }^{21}$

${ }_{21}$ Dentre essas comunicações: "gostaríamos de agradecer a oportunidade de publicar a obra EXPERIÊNCIAS E INTERPRETAÇÕES DO SAGRADO, a qual chegou a tantas 
Em relação a outras editoras procuradas, em uma das diversas vezes em que procurei a Vozes com o fito de que publicassem a produção da ABHR após 2013, recebi esta mensagem (muito cortês, por sinal):

Professor, de fato, como eu tinha adiantado, temos interesse na área da História das Religiões. No entanto, o perfil do projeto proposto não está dentro do que estamos buscando. Mesmo em áreas de público mais amplo, obras com este perfil de reunião de textos, sem uma unicidade, estão perdendo cada vez mais o espaço. Então, estamos mais voltados para obras mais orgânicas, de menos autores, ou com um projeto pensado em conjunto, com uma lógica interna entre os textos. Por isso, lamento informá-lo de que o projeto não foi aprovado para publicação. ${ }^{22}$

Foi realmente uma lástima a interrupção da publicação das obras de simpósios da ABHR através da Paulinas. Afinal, tais publicações eram fundamentais e estratégicas, como bem sinalizava Vasni de Almeida:

As edições foram compreendidas como estratégias significativas no sentido de romper as barreiras ainda existentes nas publicações e circulação de temas sobre religiões e religiosidades, fossem elas em bibliotecas dos cursos de graduação ou em programas de pós-graduação. A força da Paulinas no meio editorial brasileiro foi concebida como estratégica para a aceitação da ABHR no campo acadêmico/científico, em um momento em que os cursos, os programas e as casas publicadoras universitárias davam pouca atenção ao que se produzia nos estudos sobre religiões (ALMEIDA, 2020).

pessoas, portando muitos conhecimentos e valores. Obrigado pela parceria e pelo projeto em comum compartilhado. Como é de seu conhecimento, a obra estava em promoção desde 24 de março de 2016 e, após criteriosa análise sobre a circulação da obra, não mais reeditaremos e a colocamos à sua disposição. Informamos, ainda, que não possuímos mais exemplares em nosso depósito central, mas que poderá ou não encontrar as obras em nossas livrarias. Agradecemos mais uma vez a oportunidade de ter tido as obras em nosso catálogo e de tê-las como parceira de Paulinas." (email recebido por Silas em 26 de abril de 2017). De forma semelhante: "Fazendo um levantamento das obras com baixa circulação, nos deparamos com a obra RELIGIÃO, CARISMA E PODER.” (email recebido por Silas em 07 de junho de 2017). E ainda: "Paz e bem! É com grande prazer que relembramos nossa parceria de 14 anos com a obra RELIGIÃO E VIOLÊNCIA, $A B H R$. Fizemos um levantamento sobre a circulação da obra e constatamos que ela teve um papel importante, mas atualmente as vendas estão abaixo da média e por isso não vamos reeditá-la (...) Contamos com sua habitual compreensão e estimamos manter nossa cordial relação editorial." (email recebido por Silas em 16 de maio de 2018). Vemos assim que, infelizmente, dadas contingências mercadológicas, a Paulinas foi paulatinamente deixando de editar as obras da ABHR.

22 Comunicação por e-mail com Aline S. Carneiro, editora da Vozes (28 dez. 2017). 
Aliás, é também uma pena que outras editoras não tenham tido o interesse na publicação das coletâneas de nossos eventos. De todo o modo, além dos dois volumes impressos produzidos pela Fonte Editorial em 2013, e com o desinteresse de editoras como a Paulinas, Vozes e Paulus (e também Arché e Metanoia, dentre outras) em produzir o material referente aos Simpósios que vieram depois, me incumbi de encabeçar a produção das obras relativas aos eventos que coordenei.

Procurei seguir aqui indicação constante na Ata da Assembleia Geral do VIII Simpósio Nacional da ABHR (2006), em que Silas Guerriero ressaltou que a organização dos livros da Coleção ABHR, fruto dos eventos, é de inteira responsabilidade das pessoas que organizam eventos da associação, devendo estas ser filiadas à ABHR. ${ }^{23}$ Assim, a produção bibliográfica da maioria dos Simpósios da ABHR após 2013 foi publicada em 2018 e 2019, sem ônus para a Associação, pela editora em que colaboro, a Fogo Editorial. ${ }^{24}$

Voltando à produção do primeiro Simpósio Sudeste da Associação, ainda que tivéssemos obtido importantes recursos, ainda faltavam apoios financeiros para trazer palestrantes. Não obstante, convidei Nicola Gasbarro, importante nome da Escola Italiana de Religiões, e Stewart M. Hoover, estadunidense célebre nos estudos sobre mídia e religião, para proferir conferências no Simpósio. Faltava "só" financiá-los. A esta altura do campeonato eu começava a repensar a carpintaria de um simpósio regional - afinal, se já tínhamos os aceites de Nicola e Stewart, por que não realizarmos um Simpósio Internacional?

Aí me lembrei que Vagner Gonçalves da Silva, professor que coordenava o Programa de Pós-graduação em Antropologia (PPGAS) da USP, com experiência em Antropologia das Religiões e com estudos profícuos sobre intolerância religiosa, poderia porventura se interessar

23 O VIII Simpósio Nacional da ABHR foi intitulado Religião, raça e identidade, e realizado na Universidade Federal do Maranhão (UFMA). Sua Assembleia Geral Ordinária foi realizada em 05 de maio de 2006. Informações constantes das Atas das Assembleias da ABHR. (www.abhr.org.br). Para maiores referências acerca do apoio da Paulinas à ABHR, recomendo leitura das Atas das Assembleias e também de texto de Vasni de Almeida (2020).

24 A produção bibliográfica dos simpósios da ABHR que tive a honra de coordenar encontra-se disponível gratuitamente em forma de eBook nos sítios www.amarfogo.com e www. fogoeditorial.com.br. 
em coordenar o evento comigo. De fato, ele se entusiasmou e muito cordialmente se dispôs a fazer todos os pedidos necessários junto às agências de fomento. $\mathrm{O}$ aceite de Vagner deu novo fôlego ao evento. Foi um alívio saber que teríamos mais trabalho para a frente e que eu estaria amparade por pessoas com larga experiência na organização de eventos e bastante afinadas com o seu tema gerador ("Diversidades e (In)Tolerâncias Religiosas"). A Comissão Organizadora que se formou na sequência convidou mais seis palestrantes internacionais e o Simpósio ganhou proporções maiores do que o anteriormente delineado, se tornando o primeiro Simpósio Internacional da ABHR. ${ }^{25}$

A partir deste momento de 2013, como considero, a ABHR deu passos cada vez mais firmes para seu processo de internacionalização, concomitante ao processo de regionalização iniciado no mesmo ano, através deste e de mais dois eventos regionais anteriores a este. Contudo, antes de comentar sobre o evento que coordenei com Vágner, vou esboçar algumas linhas sobre a arquitetura do processo de regionalização da ABHR.

\section{Regionalização da ABHR durante a Gestão 2013-2015}

A sétima gestão da Diretoria Executiva da ABHR reproduziu a mesma formação da gestão anterior (2011-2013), com Wellington Teodoro da Silva (PUC/MG) na Presidência, Vasni de Almeida (UFT) na Secretaria Geral, Daniel Rocha (UFMG) na Secretaria de Divulgação e Ítalo Domingos Santirocchi (UFMA) na Tesouraria. Esta gestão foi responsável pelo início da regionalização da ABHR. A regionalização da Associação Brasileira de História das Religiões (ABHR) tem uma ideia motriz: contribuir para a expansão, fortalecimento e consolidação de análises acadêmicas de fenômenos relacionados às religiões e

25 Além de Nicola Gasbarro (Universidad de Udine) e Stewart Hoover (University of Colorado), o evento ainda recebeu a participação das seguintes pessoas estrangeiras em Mesas Redondas: Ileana Hodge Limonta (Departamento de Estudios Sociorreligiosos Del Centro de Investigaciones Psicológicas y Sociológicas, CITMA); Emmanuelle Kadya Tall (IRD/ EHESS, Paris); Yumei de Isabel Morales Labañino (Centro Cubano de Antropologia, Universidade de Havana; Tomás Fernández Robaina (Biblioteca Nacional de Cuba); John F. Collins (Latin American Studies, Queens College \& the Graduate Center/CUNY). O Simpósio acolheu em Mesas Redondas sete pessoas estrangeiras (sem contar Heidi Campbell (Texas University), que confirmou presença mas não conseguiu vir ao evento). 
religiosidades em todas as regiões do Brasil, da maneira mais ampliada e democrática possível, proporcionando e estimulando intercâmbios acadêmicos entre pesquisadoras/es.

A estratégia para o alargamento e aprofundamento destas pesquisas e diálogos está, em um primeiro momento, na realização de Simpósios Regionais, a ser articulados pela Diretoria Executiva e Coordenações Regionais, e concretizados bienalmente, em anos ímpares. Às Coordenações Regionais, cabe também estimular o avanço de trocas acadêmicas através de grupos de discussão, encontros, publicações e parcerias interinstitucionais. A regionalização da ABHR se justifica por ocorrer em um contexto de horizontalização do conhecimento, a partir de centros acadêmicos que têm surgido e/ou se consolidado no interior das regiões brasileiras, o que se constata pela crescente ampliação do interesse de muitas pessoas inclusive das que se encontram longe das grandes capitais - em realizar estudos que têm as religiões e religiosidades como mote.

O movimento de regionalização da ABHR coincide com a Estratégia 13.7, da Meta 13, do atual Plano Nacional de Educação (PNE), que vigerá de 2014 a 2024, e que propõe fomentar "a formação de consórcios entre universidades públicas de educação superior, com vistas a potencializar a atuação regional, inclusive por meio de plano de desenvolvimento institucional integrado, assegurando maior visibilidade nacional e internacional às atividades de ensino, pesquisa e extensão", de acordo com a Lei no 13.052, de 25 de junho de 2014, que entre outras ações, aprovou o novo PNE. Como bem explicava Wellington,

um único simpósio anual não conseguiria fazer a ABHR contribuir para o campo de estudo das religiões segundo as singularidades de cada lugar do país. Os grandes eventos possuem um alcance horizontalizado sem, contudo, capilarizar-se como pede o atual momento brasileiro. O grande tamanho do país também é impeditivo para os diversos pesquisadores e estudantes acompanharem os eventos nacionais. A regionalização permite a promoção de até cinco eventos em um mesmo ano com adensamento local. A figura do coordenador regional cria condições para as articulações acadêmicas nesse nível com imensas possibilidades de interlocuções com vistas à publicações e parcerias interinstitucionais. Dentre essas ações, a principal seria a articulação entre as pós-graduações locais em atividades comuns (SILVA, 2013, p. 12). 
A regionalização foi decidida durante a Assembleia Geral do XII Simpósio Nacional da ABHR, realizado em 2011, na Universidade Federal de Juiz de Fora (UFJF). Nesta reunião o novo Estatuto Social foi discutido e aprovado pela Assembleia, porém, com pendências a serem solucionadas até a próxima Assembleia. Foi aprovada a criação das Coordenações Regionais e de seus respectivos Simpósios (a primeira aparição em ata de sugestão de regionalização, vale notar, foi feita por Mabel Salgado Pereira ${ }^{26}$ em 2005). O associado Mauro Passos destacou durante a reunião que a organização de eventos regionais devia levar em consideração as especificidades regionais contemporâneas. Algumas pessoas foram indicadas para as primeiras Coordenações Regionais desta gestão, por assim saber: Lyndon Araújo dos Santos (UFMA) para a Regional Norte (ainda que o Maranhão esteja na região Nordeste, mas por falta de pessoa a ser indicada para a região Norte), Mauro Passos (PUC-MG) para a Regional Sudeste, e Eduardo Gusmão de Quadros (PUC/GO) para a Regional Centro-Oeste. Para a Regional Sul Karina Bellotti (PUC-PR) seria consultada acerca do interesse e a Diretoria Executiva definiria quem coordenaria a Regional Nordeste. ${ }^{27}$ Silva observa que neste evento

foi aprovado o novo estatuto que promoveu a reestruturação da entidade. Sua maior mudança foi a regionalização com a consequente bianualização dos seus simpósios nacionais. Eles passaram a acontecer nos anos pares. Os simpósios regionais também acontecerão bianualmente, nos anos ímpares, iniciando em 2013. Esse documento começou a ser pensado e produzido na gestão eleita no ano de 2008. A necessidade de propor uma nova organização para a entidade já era algo ressentido por muitos colegas. Eles compreendiam o lugar cada vez mais relevante e o seu crescente alcance no meio acadêmico no território brasileiro (SILVA, 2013, p. 11).

26 A Assembleia Geral Ordinária do VII Simpósio Nacional da ABHR (O sagrado e o urbano: diversidades, manifestações e análises), realizada em 05 de maio de 2005, nas dependências do anfiteatro da Pontifícia Universidade Católica de Minas Gerais (PUC-MG), em Belo Horizonte, destacou-se, dentre outras coisas, por sugestão de Mabel Salgado Pereira de que os eventos da ABHR fossem realizados em todos as regiões, visto a mesma se tratar de uma associação nacional - o que aponta para uma primeira expressão oficial, em Assembleia, da intenção de regionalização da associação. Estas informações constam das Atas das Assembleias da ABHR, disponíveis outrora no sítio oficial www. abhr.org.br.

27 Informações constantes das Atas das Assembleias da ABHR (www.abhr.org.br). 
Sobre a regionalização (disposta no novo Estatuto Social), Terzetti Filho apontou igualmente que "durante o $12^{\circ}$ Simpósio Nacional, de 2011, realizado em Juiz de Fora (MG), percebeu-se a necessidade de se estruturar a entidade a partir de eventos regionais, já que a regionalização poderia contribuir para evidenciar as especificidades de cada contexto de pesquisa." (TERZETTI FILHO, 2013, p. 193). Importa ressaltar que, destarte este Estatuto Social ter sido aprovado em Assembleia, até 2019 ele nunca foi regularizado (o que equivale a afirmar que a ABHR nunca foi corretamente institucionalizada) - destarte os incansáveis esforços de todas as gestões posteriores à aprovação do Estatuto Social. Atualmente, a advogada Marselha Evangelista de Souza (Mestra em Ciências da Religião pela UFJF), contratada pela ABHR em 2018, tem feito seus melhores exercícios para regularizar corretamente a Associação, ao que lhe desejo completo êxito.

Os primeiros Simpósios Regionais da ABHR, relativos a três regiões (Nordeste, Sul e Sudeste), foram realizados em 2013, sendo que o $1^{\circ}$ Simpósio Sudeste aconteceu concomitantemente ao $1^{\circ}$ Simpósio Internacional da ABHR e o $1^{\circ}$ Fazendo Arte da ABHR, conjunto de atividades artísticas da Associação. Em ordem de realização, ocorreram os seguintes encontros em 2013:

a) $1^{\circ}$ Simpósio Nordeste da ABHR, com o tema Religião, a herança das crenças e as diversidades de crer, na Universidade Federal de Campina Grande (UFCG), entre 28 a 31 de maio de 2013, com a Organização Geral de João Marcos Leitão Santos (UFCG);

b) $1^{\circ}$ Simpósio Sul da ABHR, com o tema Cartografias do sagrado e do profano: religião, espaço e fronteira, nas Faculdades EST, São Leopoldo, Rio Grande do Sul (RS), entre 17 e 19 de outubro de 2013, sob a Organização Geral de Oneide Bobsin (EST), Valério Guilherme Schaper (EST) e Iuri Andréas Reblin (EST); e

c) $1^{\circ}$ Simpósio Sudeste da ABHR $-1^{\circ}$ Simpósio Internacional da ABHR, com o tema Diversidades e (In)Tolerâncias Religiosas; na Universidade de São Paulo (USP), entre 29 e 31 de outubro de 2015, com a Coordenação de Vagner Gonçalves da Silva (USP) e minha. ${ }^{28}$

28 A produção bibliográfica do terceiro evento contou, além dos Anais e Caderno de Programação e Resumos, com dois volumes do livro referente a palestras em Mesas Redondas e conferência de encerramento, sendo que o primeiro volume foi lançado no próprio evento. Em 2013, por contingências alheias à competente Diretoria Executiva da época, não foram realizados os Simpósios Regionais Norte e Centro Oeste. 
Não tive o prazer de participar do $1^{\circ}$ Simpósio Sul, que Wellington me contou ter sido excelente, mas participei do $1^{\circ}$ Simpósio Nordeste, conduzido com maestria pelo simpatissíssimo João Marcos. Foi um evento que transpirou cultura nordestina e afetos, e me inspirou sobremaneira a pensar artisticamente os eventos que coordenei na Associação. Também tive a oportunidade de conhecer um pouco da cidade de Campina Grande (Paraíba), onde o evento foi realizado, na companhia de muitas pessoas instigantes. Escutamos música da região, comemos da culinária local, e tudo foi fabuloso - afinal, faz parte de participar de um simpósio (como os proporcionados pela ABHR) conhecer pessoas e costumes novos, belezas locais, e se enriquecer como gente. Nem imaginava eu que retornaria a este belíssimo estado em 2018, por ocasião do meu Pós-Doutorado em Ciências das Religiões na UFPB ${ }^{29}$ - e que nesta universidade coordenaria o $3^{\circ}$ Simpósio Nordeste da ABHR, com o tema Religião, Direitos Humanos e Laicidade; Resistências, Diversidades e Sensibilidades (2019).

Todos estes eventos, como de costume na ABHR em relação aos Simpósios Nacionais, receberam a participação de pesquisadorxs das áreas mais diversas, como Wellington já assinalava:

O dado de não ser uma associação organizada pelo recorte disciplinar tais como as associações de historiadores, de cientistas sociais, de filosofia, de teologia ou de ciências das religiões, por exemplo, é altamente significativo. O objeto produtor de sentido e coesão dessa entidade é a religião como tema de estudo. Ela nos permite pensar na existência entre nós de uma demanda reprimida sobre o estudo das religiões. (SILVA, 2013, p. 15).

É neste sentido que a ABHR pode ser considerada uma Associação de Estudos de Religião, tanto que já houve discussões acaloradas a respeito da mudança de nome e sigla (de ABHR para ABER), como observado por Silva (referido mais acima neste texto). Mas retornemos ao primeiro Simpósio Internacional / Regional Sudeste da Associação.

29 Supervisionado por Carlos André Cavalcanti (UFPB), a quem agradeço a gentil acolhida! 


\section{3: o primeiro Simpósio Sudeste da ABHR: abrindo caminhos $^{30}$ para o primeiro Simpósio Internacional da ABHR}

Neste tópico do texto, referente ao nosso primeiro Simpósio Internacional / primeiro Simpósio Sudeste, me referi às pessoas que integraram as Comissões Organizadoras e Científicas, como aos temas de GTs, Mesas e Minicursos.

Peço o perdão pela indelicadeza, mas por conta da extensão da publicação, não poderei me referir expressamente a todas as pessoas que compuseram as Comissões Organizadoras e Científicas (nem a todos os temas de atividades) dos demais Simpósios que coordenei na ABHR - a quem constituiu tais Comissões e participou de atividades destes eventos, por favor sintam-se todes abraçades fraternalmente e recebam as melhores vibrações possíveis de profundo respeito, carinho e gratidão.

Convidei Vagner Gonçalves da Silva para que proferisse nossa Conferência de Abertura ${ }^{31}$ - ou que "abrisse os trabalhos" do evento, para utilizar uma expressão das religiões afro-indígenas. Tendo como tema os caminhos de Exu (orixá para algumas religiões, entidade para outras, e costumeiramente discriminado pelo senso comum), parecia o intróito ideal para um evento sobre diversidades e (in)tolerâncias. O nome de sua Conferência foi Nas Encruzilhadas das Religiões. ${ }^{32}$

Vale, à propósito, realçar a importância de Vagner para a realização do evento: além de sua cordialidade em acolher a ABHR, de reunir pessoas em sua casa (onde quase na entrada se destacava uma plaquinha "Exu te ama", remetendo ao slogan "Jesus te ama"), de pe-

30 Sobre caminhos e portas que se abriam (e algumas que aparentemente se trancavam), é válido recordar o título do artigo de Celso Terzetti Filho sobre o evento, "Uma porta para o diálogo: o Simpósio Sudeste e Simpósio Internacional da ABHR”, publicado na REVER (PUC-SP) em 2013.

31 A Conferência foi antecedida por Mesa de Abertura com as seguintes pessoas: Wellington Teodoro da Silva (Presidente da ABHR); Andréa Gomes Santiago Tomita (Coordenadora do Fazendo Arte); Arnaldo Érico Huff Júnior (Editor-chefe da PLURA); eu e Vágner (Coordenadorxs do evento).

32 Como explica nosso Caderno de Programação e Resumos, "Nas encruzilhadas das religiões trata-se de uma discussão sobre as transformações pelas quais passa o orixá Exu num diálogo de longa duração que envolve comunidades religiosas da África e das Américas, enfatizando sob a perspectiva da circularidade cultural alguns conteúdos desse encontro religioso entre concepções cristãs e africanas que se transformam mutuamente. A mediação e os conflitos que a figura de Exu sintetiza nesse diálogo em termos de aproximações e distanciamentos (nesse caso de intolerância religiosa) será um dos pontos centrais da discussão proposta" (ABHR, Caderno de Programação..., 2013, p. 25). 
dir financiamentos, foi ele quem possibilitou que o evento tivesse os espaços reservados garantidos - o evento foi de alguma forma envolto em tempestade, visto que havia à época uma paralização estudantil na USP que promovia um "trancaço" (fechamento dos portões externos) e um "cadeiraço" que impedia a entrada nas salas de aula. Mas Vagner conduziu a situação de modo magnífico, conversando com as/os/es manifestantes e garantindo a circulação das pessoas participantes do evento. Como brincávamos, nós da Comissão Organizadora, ${ }^{33}$ foi um autêntico trabalho de Exu para abrir os caminhos e porteiras do evento. Terzetti Filho notou, neste sentido, que

infelizmente, no primeiro dia do Simpósio (dia 29), por conta das manifestações estudantis, houve um "trancaço" dos portões da Universidade, bem como o bloqueio das salas de aula, por barricadas de cadeiras que seriam utilizadas para os GTs. O contratempo, no entanto, não prejudicou o andamento do evento, já que a organização conseguiu contornar a situação disponibilizando outras salas, porém, por conta dessas manifestações e devido à tomada da reitoria pelos manifestantes, o Simpósio não contou com o financiamento interno da USP. (TERZETTI FILHO, 2013, p. 194).

O primeiro Simpósio Internacional da ABHR (concomitantemente o primeiro Simpósio Sudeste da Associação) foi realizado entre 28 e 31 de outubro de 2013, tendo mais de 750 pessoas regularmente inscritas participando do evento (além de pessoas não inscritas participando como ouvintes). Mas o sucesso do evento não esteve na amplificada quantidade de pessoas presentes, somente - esteve especialmente na qualidade das apresentações e em sua diversidade temática: como um evento que tinha "diversidades" como mote, não deixou nada a desejar em relação ao tradicional acolhimento da ABHR de assuntos variados que se relacionam ao fenômeno religioso.

33 Não há palavras para agradecer estas pessoas: Jacqueline Moraes Teixeira (USP); Jacqueline Ziroldo Dolghie (UMESP); João Enicelio da Silva (Mackenzie); Joelma Santos da Silva (UFMA); Rosenilton Silva de Oliveira (USP); Sandra Duarte de Souza (UMESP); Talita Sene (UFSC); Cleto de Abreu (USP); Carlos Gutierrez (UNICAMP); e Helena Manfrinato (USP); além da Comissão Editorial composta por Daniel Rocha (UFMG); Ítalo Santirocchi (UFRRJ); Joelma Santos da Silva (UFMA); Kate Rigo (EST); Sandra Duarte de Souza (UMESP) e Talita Sene (UFSC); e da Comissão do Fazendo Arte, composta por Andrea Santiago Tomita e Juliana Graciani (Messiânica). 
Propus que realizássemos o primeiro Prêmio de Pôsteres da Associação, e sua Comissão Científica ${ }^{34}$ foi formada pelo casal Mundicarmo Maria Rocha Ferretti (UEMA) e Sergio Figueiredo Ferretti (UFMA), Lauri Emílio Wirth (UMESP), Solange Ramos de Andrade (UEM), Lyndon Araujo Santos (UFMA) e Gedeon Freire de Alencar (PUC-SP). ${ }^{35}$ Durante esse evento foi realizada também homenagem - em vida - ao casal Mundicarmo ${ }^{36}$ e Sérgio Ferretti ${ }^{37}$, referências nos estudos de religiões e religiosidades afrobrasileiras e afroindígenas e com contribuições históricas à ABHR. A homenagem foi conduzida, a meu convite, por Lyndon de Araújo Santos.

34 Além da Comissão Avaliadora dos Pôsteres, o primeiro Simpósio Internacional / Simpósio Sudeste da ABHR contou com magnífica Comissão Científica Geral, composta por: Adone Agnolin, USP; Andréa Gomes Santiago Tomita, Messiânica; Antonio Máspoli de Araujo Gomes, Mackenzie; Airton Luis Jungblut, PUC/RS; Artur César Isaia, UFSC; Edgard Leite Ferreira Neto, UERJ; Edin Sued Abumanssur, PUC/SP; Edlaine Campos Gomes, UniRio; Eduardo Gusmão de Quadros, UEG; Eliane Moura da Silva, UNICAMP; Elizete da Silva, UEFS; Elton Nunes, Messiânica; Émerson José Sena da Silveira, UFJF; Ênio Brito, PUC/SP; Etienne Higuet, UMESP; Fernando Torres-Londoño, PUC/SP; Flávio Augusto Senra Ribeiro, PUC/MG; Frank Usarski, PUC/SP; Gedeon Freire de Alencar, ICEC; Gisele Zanotto, UPF; João Marcos Leitão Santos, UFCG; José Guilherme Cantor Magnani, USP; Paula Montero, USP; Karina Kosicki Bellotti, UFPR; Lauri Emilio Wirth, UMESP; Leonildo Silveira Campos, UMESP; Lyndon de Araújo Santos, UFMA; Marcelo Tavares Natividade, UFC; Magali do Nascimento Cunha, UMESP; Maria Luisa Tucci Carneiro, USP; Maria José Fontelas Rosado-Nunes, PUC/SP; Mundicarmo Maria Rocha Ferretti, UFMA; Sérgio Figueiredo Ferretti, UFMA; Silas Guerriero, PUC/SP; Solange Ramos de Andrade, UEM; Sônia Weidner Maluf, UFSC; Wellington Teodoro da Silva, PUC/MG; Zwinglio Motta Dias, UFJF.

35 A premiação ocorreu no dia 31 de outubro de 2013, durante a Mesa de Encerramento do evento, composta por Nicola Gasbarro, Adone Agnolin e por mim. As três pessoas premiadas receberam, das mãos das pessoas participantes da Mesa, diversos livros ofertados pelas editoras que compuseram o evento. Tanto o Prêmio de Pôsteres como o Fazendo Arte foram propostas minhas implementadas neste simpósio e que foram desenvolvidas nos simpósios posteriores que coordenei na ABHR.

36 Mundicarmo Maria Rocha Ferretti é Professora emérita e titular aposentada na UEMA; Professora adjunta IV aposentada na UFMA; Doutora em Antropologia Social pela USP; Mestra em Ciências Sociais pela UFRN e em Administração Pública (Pessoal) pela FGV - RJ.

37 Sérgio Figueiredo Ferretti: Professor Emérito na UFMA; Doutor em Antropologia Social pela USP; Mestre em Ciências Sociais pela UFRN. Falecido em 23 de maio de 2018, recebeu homenagem póstuma da ABHR através de carta e durante o último Simpósio Nordeste da ABHR, em 23 de maio de 2019. 
Além de toda o programa usual dos eventos da ABHR, foi realizado o $1^{\circ}$ Fazendo Arte da ABHR, ${ }^{38}$ que idealizei como um conjunto de atividades artísticas envolvendo múltiplas performances ${ }^{39}$ e exposições. ${ }^{40}$ Terzetti Filho contemplou que

Durante os três dias do Simpósio, aconteceu o Fazendo Arte, espaço de manifestação artística que contou com uma programação de expressões diversificadas, que incluíam apresentações de dança, grupos musicais, cantores, performances de expressões corporais e exposições. As apresentações ocorreram na Casa de Cultura Japonesa. (TERZETTI FILHO, 2013, p. 195).

Lamento muito por não poder retratar toda a riqueza de talentos apresentada no primeiro de nossos Fazendo Arte, mas seguem algumas imagens que ainda tenho (afetivamente) guardadas.

38 O primeiro Fazendo Arte da ABHR foi coordenado por Andréa Gomes Santiago Tomita (Faculdade Messiânica) e por mim, com vice-coordenação de Juliana Graciani ((Faculdade Messiânica).

39 Elegbara; Brazil; M'Borai; Músicas de Arnaldo Huff; Aqualtune: a Princesa do Quilombo dos Palmares; Tribal Fusion; Pedacinho de Mulambo; Rosa Vermelha; Iansã; Show da Noise Pop Rock. Para ver xs artistas, acessar o Caderno de Programação e Resumos do evento (ver link ao final do artigo).

40 Através dos olhos; Desenhos e aquarelas; Etnografia de um terreiro paulista; Os pecados de São Tomás de Aquino na pós-modernidade: as mazelas de ser humano; Os vícios de Aristóteles na pós-modernidade: as delícias de ser humano; Paraíso terrestre em perspctiva; "Pausa reflexiva"no quadro (in)tolerâncias religiosas; Salamandra - onde ciganos se encontram; Um olhar sobre a religiosidade de matriz africana; e ainda uma Vivência de Arte Ikebana Sanguetsu, além da apresentação do filme Portunhol. Para ver xs artistas, acessar o Caderno de Programação e Resumos do evento. 
em sua regionalização e internacionalização (2013 a 2015)

Imagens: Pessoas associadas e convidadas apresentando exposições de objetos e indumentárias religiosas, pinturas, música, dança e teatro (Primeiro Fazendo Arte da ABHR)

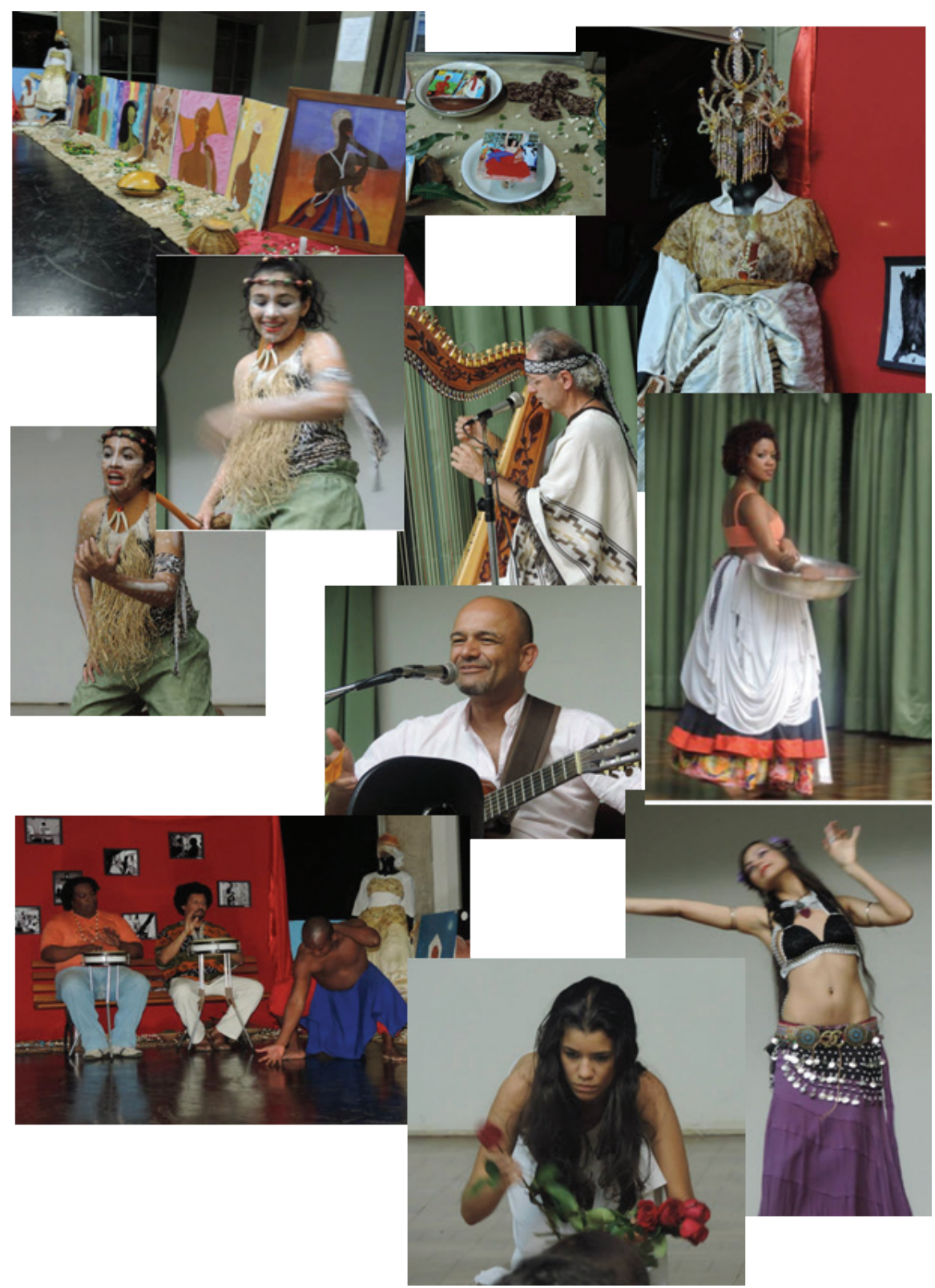

Fonte: Arquivo pessoal 
Imagem: Vagner Gonçalves da Silva (USP) conversa durante Coquetel Orgânico com o casal Mundicarmo e Sergio Ferretti (UEA / UFMA) ${ }^{41}$

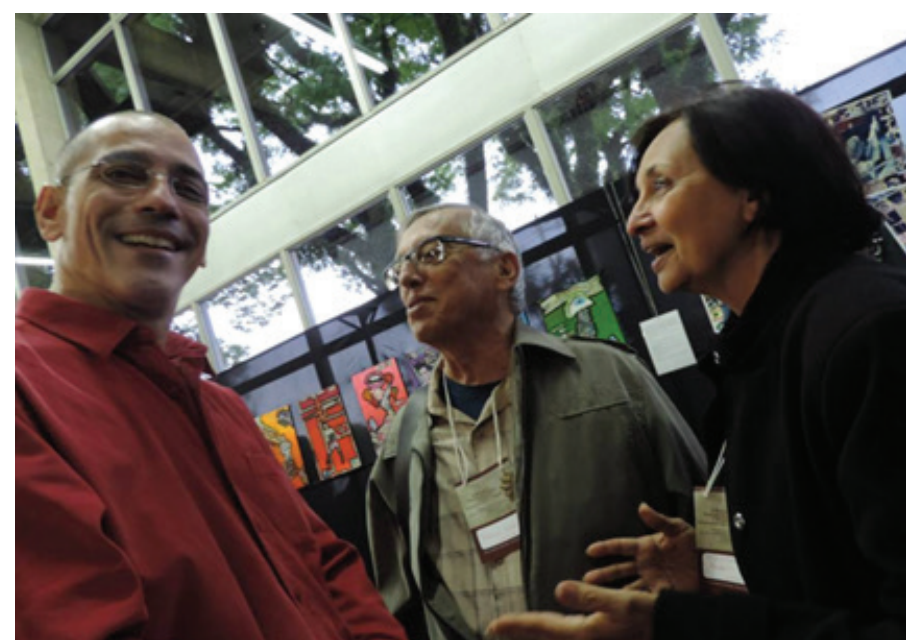

Fonte: Arquivo pessoal

Já na imagem acima, vemos Vágner conversando divertidamente com o casal Mundicarmo e Sergio Ferretti, homenageado pelo evento. Pessoalmente, não consigo deixar de lembrar das presenças agradáveis das pessoas retratadas nas imagens acima (dentre muitas outras), nem tampouco do "cheirinho do café orgânico" que exalava durante todo o dia no hall da Casa de Cultura de Japonesa da Cidade Universitária remetendo ao que Proust comentava sobre a memória, de que a melhor parte dela está fora da gente,

está numa brisa chuvosa, num cheiro de quarto fechado, ou no de um primeiro fogaréu, em toda parte onde encontramos de nós mesmos o que nossa inteligência rejeitara, por julgá-lo inútil, a última reserva do passado, a melhor, aquela que, quando todas as nossas lágrimas parecem ter secado, sabe ainda fazer-nos chorar. Fora de nós? Em nós, para melhor dizer, mas escondida a nossos próprios olhares, num esquecimento mais ou menos prolongado. É graças a tal esquecimento que podemos, de vez em quando, reencontrar o ser que já fomos, colocar-nos face a face às coisas como o era essa criatura, sofrer de novo, porque não somos mais nós mas ele, é ele quem amava a pessoa que agora nos é indiferente (PROUST, 2002, p. 493).

41 Não consigo deixar de lembrar do "cheirinho do café orgânico" que exalava durante todo o dia no hall da Casa de Cultura de Japonesa da Cidade Universitária. 


\section{O que me marcava indelevelmente não era o cheiro do quarto} fechado, mas do cafezinho e de um evento aberto que ventilava liberdade de sabores e de saberes, afetos, abraços e acolhimentos mútuos e coletivos, resistências e, claro, memórias.

Tivemos 16 Mesas Redondas em três dias de evento, ${ }^{42} 12$ Minicur$\operatorname{sos}^{43}$ e 27 Grupos de Trabalho (GTs), ${ }^{44}$ todas as atividades com ótimo

42 No dia 29 de outubro de 2013 foram realizadas as seguintes Mesas Redondas: A Paz na Terra: os 60 anos da encíclica Pacem in Terris; Teoria e metodologia dos estudos de religião; "Religiosidades" ameríndias; Políticas e religiosidades; Festas, artes e religiosidades. Em 30 /10, Itinerários, percursos e narrativas do sagrado; O que é História das Religiões?; Convivência inter-religiosa; Religiosidades, gênero e política; Religião, patrimônio e tradição; e Islamismos. No dia 31/10: Judaísmos; Religiosidades no (do) ciberespaço; Violência e religião; Religião e espaço público: novas vozes e conflitualidades; e Religiosidades e espiritualidades "orientais". Mais informações (inclusive participantes das Mesas) no Caderno de Programação e Resumos do evento (2013).

43 Aconteceram os seguintes Minicursos: Catolicismo brasileiro: neocristandade e práticas religiosas associativas (1889-1964); Direito e liberdade religiosa: teoria, litígios e perspectivas; Direito, Estado laico e religião no Brasil: limites, conflitos e convergências; Fundamentos da arquitetura islâmica; Fundamentos da filosofia-teológica de Mokiti Okada para o Despertar da Cidadania Universal; História e religiões: teoria e metodologia; Religiosidade indiana: diversidades e (in)tolerâncias sociais, animais sagrados e a mulher no hinduísmo e budismo; Santos patronos e a política católica: sécs. XVI-XVIII; Iconografia budista; A Fé Bahá'í: incompreendida e perseguida; Práticas nativas ancestrais - Xamanismo: a religião do culto à natureza; e Asé: A musicalidade corpórea poética do tambor e da Dança. Para ver todxs ministrantes, acessar o Caderno de Programação e Resumos do evento.

44 Foram realizados os seguintes GTs: GT1 - Bruxaria à brasileira: a presença da Wicca no Brasil; GT2 - Catolicismo brasileiro: neocristandade e práticas religiosas associativas (1889-1964); GT3 - Corpo, cultura e religião; GT4 - Dietrich Bonhoeffer: ética e teologia a serviço da vida; GT5 - "Edificando para Deus": a arquitetura do sagrado nas suas diferentes manifestações; GT6 - Escolas das religiões afro-brasileiras e diálogos; GT7 Escolas públicas e (in)tolerância religiosa; GT 8 - Estados Unidos: religião e sociedade; GT9 - Fundamentalismos religiosos; GT10 - Gênero e religião; GT11 - Hereges, judeus e infiéis e a intolerância religiosa no. decorrer da Idade Média; GT12 - História cultural das religiões; GT13 - História e historiografia do protestantismo no Brasil; GT14 - Igrejas inclusivas LGBTT e a luta contra a intolerância ..religiosa; GT15 - (In)tolerância, gênero e religião; GT16 - Marketing, espetáculo e ciberespaço: entre diversidades e.(in)tolerâncias religiosas; GT17 - "No templo, no quartel e no porão": os protestantes e a ditadura militar brasileira; GT18 - O Oriente e suas diversidades religiosas; GT19 - Pentecostalismos brasileiros: novas perspectivas; GT20 - Religião e ciência: tensão, diálogo e experimentações; GT21 - Religião e hierofania: história, espaços e símbolos; GT22 - Religião e política; GT23 - Religião e violência; GT24 - Religiosidade, identidade e intolerância: (novas) re-configurações da religião; GT25 - Representações, (re)leituras e relações entre religiões e.........(in)tolerâncias religiosas no cinema; GT26 - Saúde, religião e cultura: um diálogo a partir das práticas terapêuticas culturais e religiosas; e GT27 - Universos simbólicos de religiosidades no Japão. Para ver todxs coordenadorxs e comentadorxs, acessar o Caderno de Programação e Resumos do evento. 
número de participantes. O Simpósio também recebeu, antecedendo cada Mesa, uma sessão de Leitura de História de Vida Religiosa, em que foram lidas narrativas de experiências biográficas religiosas que se relacionavam de alguma forma com os assuntos das Mesas. Foi realizada ainda uma Reunião da ABHR, acolhendo as pessoas que tivessem interesse em colaborar - utilizando a expressão de Wellington, referida mais acima - de forma ativa e orgânica com a Associação.

Outra atividade que tatuou a minha alma foi o lançamento de publicações (e quem está lendo o texto vai compreender o porquê daqui há pouco). Ao todo, foram lançadas 32 publicações, em um Auditório repleto, o da Casa de Cultura Japonesa da Cidade Universitária/USP, tendo como hostess / apresentadora do lançamento a conhecida drag queen paulistana Rainha Tchaka. Até hoje pessoas presentes ao simpósio me recordam com alegria do instante em que Tchaka sentou-se no colo de Sergio Ferretti, e particularmente, me recordo das divertidas gargalhadas de Mundicarmo, que se divertia com o momento de descontração.

Durante o evento eu lançaria algumas publicações: além dos Anais e do primeiro volume do livro do evento (intitulado Religiões em (Con) Textos), ${ }^{45}$ as coletâneas Religiões e Religiosidades no (do) Ciberespaço, primeira obra brasileira organizada sobre o assunto; (Re)Conhecendo o Sagrado: Teoria e Metodologia nos Estudos de Religião; e o produto de minha dissertação, intitulado A Grande Onda vai te Pegar: Marketing, espetáculo e ciberespaço na Bola de Neve Church. ${ }^{46}$ Mas o destaque esteve nas demais obras, que costuravam temas os mais variados possíveis: Assembleia de Deus, "macumba", educação nos terreiros, islamismo, pentecostalismo, sincretismo, compêndio de ciências da religião, direitos humanos, diáspora, umbanda, e como, se esperava, História das Religiões. ${ }^{47}$

45 Publicada em 2019 pela Fogo Editorial com o título do evento, Diversidades e (In) Tolerâncias Religiosas (disponível gratuitamente nos sítio www.amarfogo.com e www. fogoeditorial.com.br).

46 São Paulo: Fonte Editorial, 2013. Lancei ainda o dossiê Marketing Religioso, da Revista de Estudos da Religião (REVER), v. 12, n.2 (2012), co-organizado por mim e Frank Usarski (São Paulo: Paulinas e PUC/SP, 2012).

47 Afinal, o que é Macumba?, de Michelle E. Soares (São Paulo: Arché Editora, 2013); Assembleia de Deus: ministérios, carisma e exercício de poder, Marina Correa (São Paulo: Fonte Editorial, 2013); Compêndio de Ciência da Religião, João Décio Passos, Frank Usarski (orgs.). (São Paulo: Paulinas/Paulus 2013); Educação nos terreiros: e como 
Imagens: Banquete de lançamento de publicações do $1^{\circ}$ Simpósio Internacional da ABHR; e Tchaka Drag Queen ao lado de Sergio Ferretti (saudoso, que lançou obra sobre sincretismo na cultura popular), Nilza Menezes (especialista em Pombagiras) e José Honório Flores (que escreveu sobre Frei Damião).

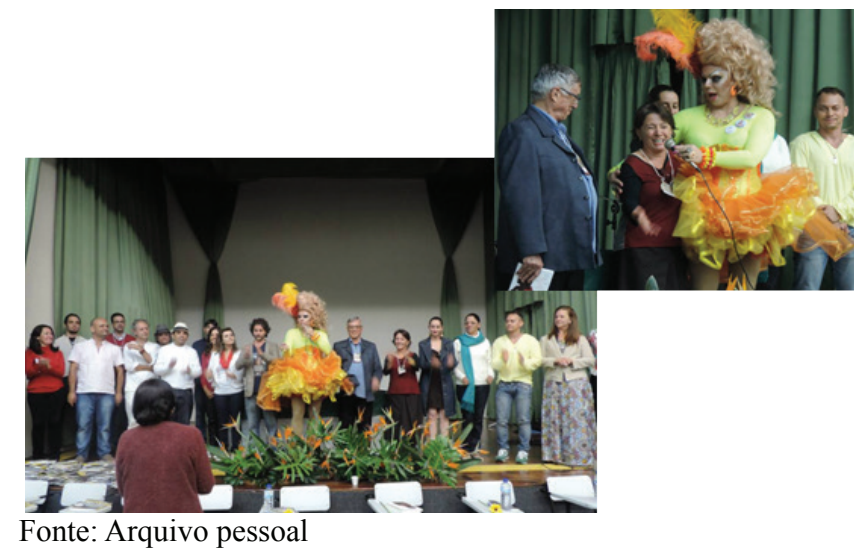

a escola se relaciona com crianças do candomblé, Stela Guedes Caputo (Rio de Janeiro: Pallas, 20120; Frei Damião - o santo popular e a edificação do ícone: a fé na modernidade e o catolicismo popular no santuário de Frei Damião, José Honório das Flores Filho (São Paulo: Fonte Editorial, 2013); História das religiões: perspectiva histórico-comparativa, Adone Agnolin (São Paulo: Paulinas, 2013); Islã e Antropologia, Revista de Estudos da Religião (REVER), v. 13, n. 1, Francirosy Campos Barbosa Ferreira (org.) São Paulo: Paulinas e PUC/SP, 2013; Matriz Pentecostal Brasileira: Assembleias de Deus - 19112011, Gedeon Freire de Alencar (Rio de Janeiro: Novos Diálogos, 2013); Missa, Culto e Tambor: os espaços das religiões no Brasil, Gamaliel da Silva Carreiro, Lyndon de Araújo Santos e Sergio Figueiredo Ferretti (orgs.) (São Luís, EDUFMA, 2012); Nkisi da diáspora: raízes bantu no Brasil, Janaína de Figueiredo (org.) (Acubalin, 2013); O Mito de Origem: uma revisão do ethos umbandista no discurso histórico, Maria Elise Gabriele Baggio Machado Rivas (São Paulo: Arché, 2013); O Rosto Ecumênino de Deus, Claudio Ribeiro e Magali Cunha (São Paulo: Fonte Editorial, 2013); Os laços entre igreja, governo e economia solidária, André Ricardo de Souza (São Carlos: EDUFSCar, 20130; Oporai Guata Porã: Awaju Poty, João José de Felix Pereira (CD, 2000); Pentecostalismos e transformação social, David Mesquiati (org.) (São Paulo: Fonte Editorial, 2013); Religião e Direitos Humanos, PLURA - Revista de Estudos de Religião da ABHR, v. 4, n.1 (2013); Protestantes, evangélicos e (neo)pentecostais: história, teologias, igrejas e perspectivas, Zwinglio Mota Dias, Elisa Rodrigues, Rodrigo Portella (Orgs.) (São Paulo: Fonte Editorial, 2013); Protestantismo e História: Brasil e França na visão de Émile Léonard, por Marcone Bezerra Carvalho (São Paulo: Editora Mackenzie, 2013); Repensando o sincretismo, Sérgio Figueiredo Ferretti (São Paulo: Arché/EDUSP, 2013); Revista Estudos de Religião, v. 2 7, n0 2, 2013, Último Andar (PUC-SP, 2013); Todas as águas vão para o mar: poder, cultura e devoção nas religiões, Gamaliel da Silva Carreiro, Lyndon de Araújo Santos, Sérgio Figueiredo Ferretti, Thiago Lima dos Santos (orgs.) (São Luís: EDUFMA, 2013); Umbanda e Teologia da Felicidade, Fernanda Ribeiro (São Paulo: Arché, 2013). 
Este momento de confraternização de conhecimentos foi super exitoso. Mas acabou sendo "carimbado" por outro acontecimento, digamos, nada digno de festejos. Minutos antes de Tchaka Drag Queen entrar de modo triunfante no Auditório, eu fui interpelade na porta do mesmo por um homem de terno que estava acompanhado de dois rapazes aparentando serem seguranças deste, e lutadores de jiu jitsu ou muay thai.

O rapaz de terno se apresentou como advogado da Bola de Neve (BDN), enquanto os dois moços não se apresentaram. A primeira coisa que o advogado disse foi que se eu publicasse, lançasse ou divulgasse o livro A grande onda vai te pegar: Marketing, espetáculo e ciberespaço na Bola de Neve Church, eu "iria ter problemas". Alegou que eles tinham propriedade intelectual do nome da igreja e que o nome estava na capa, e que aquele era um livro comercial e não acadêmico (mal sabiam que pelo acordo com a editora eles iriam me encaminhar uma pequena parcela em livros, e nada em dinheiro). ${ }^{48}$ Algumas pessoas que estavam no evento testemunharam esta tentativa de coerção da igreja. Mas quais, afinal, seriam estes problemas que eu teria?

De início, imaginei que se tratassem de problemas de natureza jurídica, visto que o emissor da mensagem se apresentou como advogado. Entretanto, no início de novembro, advogados amigos meus me alertaram que, antes da noite de 30 de outubro, a BDN já havia entrado com ação para retirada do livro de circulação - pedido indeferido por juiz - e com recurso, indeferido por desembargador. Ficou uma inquietação geral: se o advogado da igreja me procurou (ameaçou) dizendo que eu teria problemas, mas já havia entrado com ação e recurso - ambos indeferidos pela Justiça, e ao me procurar (ameaçar) não citou tais ações na Justiça, quais seriam afinal estes problemas?

A censura se iniciou em 28 de outubro de 2013, através de uma ação judicial de indenização que procurou proibir o lançamento, publicação e circulação do livro. A ação pedia ainda que o evento de lançamento na USP fosse cancelado, que eu retirasse de circulação tudo que já publiquei sobre a igreja (artigos em revistas, capítulos de livros, etc), que eu nunca mais mencionasse o nome da mesma em trabalhos futuros, e previa uma multa caso eu tivesse lançado o livro no dia 30:

48 E a bem da verdade, essa parcela nunca foi me encaminhada corretamente. 
$\mathrm{R} \$ 50$ mil pelo lançamento e mais $\mathrm{R} \$ 10$ mil diários após o lançamento. Imaginemos se a ação fosse deferida, quantos precedentes prejudiciais à liberdade de expressão e pesquisa ela teria aberto? Mas a ação foi indeferida por um juiz no dia seguinte. No dia 30 de outubro, a igreja entrou com um agravo de instrumento, que também foi indeferido, desta vez por um desembargador, durante a tarde.

Ou seja, num evento sobre intolerâncias, meu livro foi intolerado, discriminado e censurado. Pessoas que estiveram no evento comentaram que, também ironicamente, o episódio de censura ocorreu às vésperas da comemoração da Reforma Protestante, indagando: seria a Bola de Neve simpatizante de uma Contra-Reforma, de caráter superconservador? Notaram ainda que era véspera da comemoração do Dia das Bruxas, que também cai em 31 de outubro. Perguntaram: será que estamos entrando novamente em um período inquisitório de caça às bruxas, ao melhor (pior) estilo do Index Librorum Prohibitorum (o índice católico de livros proibidos, que perdurou até 1966), ou o Malleus Malleficarum? O Martelo das Bruxas começará a bater de novo? ${ }^{49}$ Haverá o estímulo a que fieis queimem livros considerados diabólicos antes mesmo de sua leitura $?^{50} \mathrm{O}$ quanto esse episódio se assemelha ao que o filme A Onda (Die Welle, de 1988) descreve, acerca de vagas fascistas que se avizinham?

Não sei o quanto perguntas como essas eram inflamadamente exageradas. Fiéis e ex-fiéis da igreja me confidenciaram que a compra e leitura do livro costuma ser proibida pela instituição através de pregações e de uma carta interna, à qual não tive acesso para atestar a veracidade de tais relatos. Também comentaram que já foram organizados círculos de oração, reuniões e vigílias em algumas unidades a fim de derrubar o inimigo ou adversário da igreja, ou o Anticristo que teria escrito a

49 Malleus Maleficarum (como é conhecido o Malleus Maleficarum Maleficat \& Earum Haeresim, ut Framea Potentissima Conterens) é o título em latim do conhecido Martelo das Bruxas ou Martelo das Feiticeiras, livro publicado por James Sprenger e Heinrich Kraemer, dominicanos alemães, em 1486 ou 1487. O livro foi publicado em atendimento à bula papal intitulada Summis Desiderantis Affectibus de Inocêncio VIII, e trata-se, provavelmente, do mais célebre dos violentos manuais de combate a heresias e seus / suas praticantes.

50 Importa notar que as ações pedindo a censura ocorreram antes do lançamento do livro, assim, a igreja não conhecia o conteúdo do mesmo. 
Bíblia Negra do Satanismo (supostamente eu). Líderes da igreja também teriam dito que o livro poderia ser comprado se servissem a um propósito específico: alimentar uma fogueira santa. Ou seja, se a censura não se consolidou em termos jurídicos, ela ainda parece rolar como avalanche dentro de unidades da Bola de Neve Church.

A censura ao livro foi noticiada pela Folha de S. Paulo e Istoé, comentada em sessão do Supremo Tribunal Federal (STF) a respeito de obras não-autorizadas, ${ }^{51}$ além da revista Caros Amigos, de resenhas acadêmicas, de artigo acadêmico (TERZETTI FILHO, Revista REVER - PUC/ SP, 2013), Revista da ESPM, Revista de História da Biblioteca Nacional, e de diversos sites, $b \log s,{ }^{52} \mathrm{CBN}$ e outras estações de rádios brasileiras (especialmente paulistanas), e páginas de redes sociais. A censura foi noticiada até em sites da longínqua China, por incrível que pareça.

Além disto, a ABHR publicou, em seu sitio, uma Carta Aberta de Recusa a tais atividades coercitivas da BDN, assinada em conjunto com a ANPUH (Associação Nacional de História), o GT de Religiões e Religiosidades da ANPUH, e a ACSRM (Associação de Cientistas Sociais de Religião do Mercosul). Também circulou entre discentes dos PPGs da FFLCH/USP uma Carta Aberta de Repúdio à Censura e de Apoio à Liberdade de Expressão e Pesquisa. O livro também foi listado pela revista Ultimato como um dos 12 livros de 2013 que as pessoas cristãs deveriam ler (QUADROS, 2013). Para Terzetti Filho

É curioso notar que, num evento que tem como tema a questão da (in) tolerância, a tentativa de censura se fizesse presente. $\mathrm{E}$ foi o que aconteceu. Um dos livros a serem lançados, A Grande Onda Vai te Pegar: Marketing, Espetáculo e Ciberespaço na Bola de Neve Church, de Eduardo Meinberg Maranhão, foi alvo de tentativa de censura por parte dos membros da Igreja citada. Um lamentável episódio (TERZETTI FILHO, 2013, p. 195).

Como diz a carta aberta conjunta da ABHR / ANPUH/GTHRR-ANPUH/ACSRM, em apoio ao livro, "impossível não nos lembrarmos da questão das biografias não autorizadas. No caso de Meinberg parece

51 A grande onda é referida a partir dos 42:35 pelo Dr. Ivar A. M. Hartmann, do Instituto Histórico Geográfico, em audiência do STF a respeito das biografias não-autorizadas. Referência e link no final do texto.

52 Dentre os blogs, destaco aqueles cujos/as autores/as das matérias me procuraram para saber minha opinião: Blog do Genizah, As pedras clamam, Uma estrangeira no mundo. 
ser a história não autorizada" (ABHR, ACSRM, ANPUH, GTHRR-ANPUH, 2013). Esta carta remete ainda a outra, assinada por 200 intelectuais brasileiros e intitulada "liberdade para as biografias", também referida, em 2017, por um site da China que comentou sobre a igreja e a censura à Grande Onda:

“历史学家写政治史时，不用问过国家或政党同意；阐述对宗 教历史的看法时，也不会祈裙得到教堂或者寺庙的保佑; 不依靠大 企业来分析经济现象。同样，传记作家写看法时，也不需要传记人 物来批准”, ou traduzindo para quem não sabe chinês (como eu), “o historiador não pede licença ao Estado ou aos partidos para escrever a história política; não solicita a benção de Igrejas ou templos para expor sua visão sobre a história das religiões; não depende de empresas ou corporações para analisar o fenômeno econômico. Do mesmo modo, o biógrafo não pode estar submetido à autorização do biografado para falar de seu personagem" (Liberdade para as Biografias, 2013).

Imagens: capa d' A grande onda vai te pegar; foto de matéria da Istoé, reproduzidas por site chinês
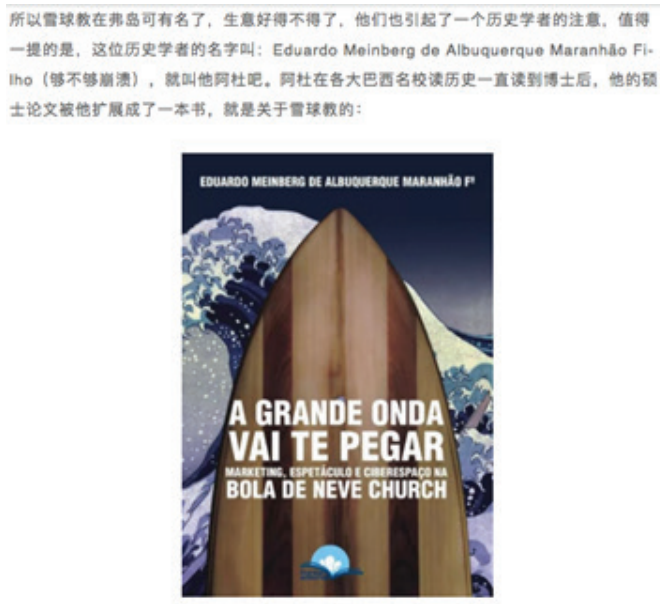

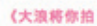

Fonte: Arquivo pessoal

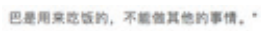

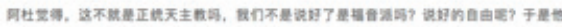

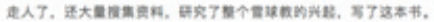

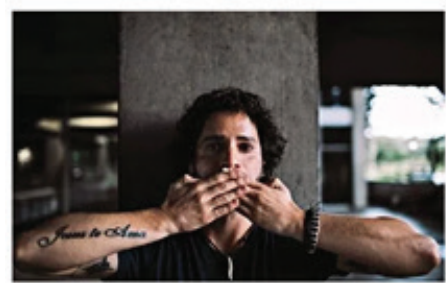

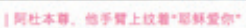

misna

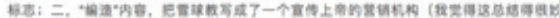

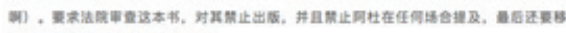

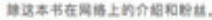


Essa inquietação de pessoas chinesas - lembrando que o Estado Chinês é conhecido por censuras e perseguições ideológicas - remete a perguntas que fiz em 2013 no jornal Brasil 247,

onde estamos agora? Censura após livro autorizado? Ou não autorizado? Histórias não autorizadas? Trabalhos acadêmicos não autorizados? Eventos não autorizados? Menções a nomes de igrejas pesquisadas não autorizadas? Cadê a liberdade de pesquisa e de expressão? Estaria rolando uma espécie de "mordaça evangélica"? (MARANHÃO Fo, 2013).

Ou semelhantemente, como indaguei em entrevista à IstoÉ, "seria o início de uma mordaça cristã em relação a trabalhos sobre evangélicos?" (CARDOSO, 2013). Ou ainda, segundo Rafael Zanvettor,

os primeiros foram os biógrafos. Foram perseguidos pelos biografados, censurados, impedidos de publicar suas obras e ainda por cima acusados de usura e ganância em um negócio que dá muito trabalho e pouco dinheiro. A ameaça à liberdade de expressão avança agora sobre os pesquisadores (ZANVETTOR, 2013).

Ivar Hartmann sinalizou neste mesmo sentido, em sessão do Supremo Tribunal Federal (STF) que comentou sobre biografias não-autorizadas. Ao dar como exemplo a tese de Livre Docência em História de Lilia Moritz Schwarcz, transformada em livro (1998) ${ }^{53}$ que traz uma biografia sobre Dom Pedro II (1998) e a dissertação (2010) que desembocou no livro que escrevi (2013), Hartmann considerou que, caso não se legisle precisamente acerca dos critérios para interdição a trabalhos acadêmicos,

cada pesquisador vai passar o resto da sua vida lendo e pensando seus trabalhos já feitos, e seus potenciais futuros trabalhos sob a ótica do censurador, sob a ótica do risco, e havendo o mínimo risco de ser responsabilizado e obrigado no mínimo a não publicar, mas pior ainda, a

53 Lilia Schwarcz comenta a questão das biografias em texto de 2013. Ela nota que "o fato é que, em tempos mais recentes, a relação entre biografia e história acabou por inserir-se em um conjunto mais vasto de contraposições que opõe indivíduo a sociedade; individual a coletivo; social a particular; estrutura a contexto; ação individual a ação coletiva. Nessa rede de dualidades tensas, oscilamos entre ver o personagem como apenas a reiteração de impasses sociais e ligados a seu grupo, ou, ao contrário, em buscar nele um caso único, particular e afeito a uma memória de si”' (SCHWARCZ, 2013, p. 54-55). 
pagar indenização, este pesquisador jamais vai produzir qualquer coisa, jamais vai produzir qualquer investigação cientifica de relevância para a sociedade brasileira (HARTMANN, 2013).

No caso da grande onda, tive ganho de causa - mas poderia ter-se decidido o contrário, abrindo-se precedente jurídico perigoso. Assim, é necessário critérios claros e objetivos que garantam a pesquisas acadêmicas a necessária legitimidade - coligados a, por exemplo, responsabilização por má fé ${ }^{54}$ e à ética de pesquisa de pessoas historiadoras (e de demais áreas) que pretendam realizar biografias (SCHMIDT, 2014). Gilbraz Aragão indagou sobre a censura: "seria uma tentativa de retomar civilmente a inquisição, agora para defender sagrados interesses de marcas e negócios?” (ARAGÃO, 2013).

Em uma das últimas Mesa Redondas ${ }^{55}$ do evento, realizada no dia 31 de outubro de 2013, e intitulada Religiões e religiosidades no (do) ciberespaço, ${ }^{56}$ Stewart Hoover (University of Colorado) comentou sobre

54 Acerca disto, Hartmann comenta: "estamos falando na necessidade da constatação de duas coisas, não só o erro em relação ao que se relata, mas também a má fé na produção do relato e desse erro, ou seja, não basta que esteja errado. Em pesquisa acadêmica muito bem sabemos que não existe verdade absoluta. Tivemos recentemente a divulgação de um novo estudo sobre Tiradentes que vem rever muito do que se tinha dito por historiadores sobre Tiradentes. Esses historiadores anteriores então devem pagar indenização? Estavam eles “errados"? Não, não estavam errados porque não existe verdade absoluta. A verdade é sempre passageira. Então não basta estabelecer critério que seja de erro, é preciso, para salvaguardar a pesquisa acadêmica no Brasil, que se trate de proibição de erro em função de má fé, má fé em relação a esse erro. Caso contrário, os pesquisadores brasileiros não só na área de História e Sociologia, mas todas as áreas, inclusive na área do Direito, não terão qualquer condição de realizar aquele trabalho que é de vital importância para a sociedade brasileira" (HARTMANN, 2013). Sobre biografia e auto-biografia, e suas relações com a feitura historiográfica, sugiro, por exemplo, Albuquerque Júnior (2012).

55 As demais mesas deste dia foram: Religião e espaço público: novas vozes e conflitualidades, com coordenação de Christina Vital da Cunha (UFF), e participação desta e de Emerson Sena da Silveira (UFJF) e Fabricio Oliveira (UFV); Religiosidades e espiritualidades "orientais", com a coordenação de Andrea Tomita (Messiânica) e participação desta e de Dilip Loundo (UFJF), Silas Guerriero (PUC-SP) e Peter Robert Demant (USP); Violência e religião, coordenada por Edin Abumanssur (PUC-SP), com participação deste e de Antonio Máspoli Gomes (Mackenzie), Valeria Vilhena (UMESP), Vagner Marques (PUC-SP), e Ana Leticia de Fiori (USP); Judaísmos (coordenada por Edgard Leite (UERJ), com a participação deste e de Marta Topel (UNICAMP), Wagner Arieh (USP) e Carlos Gutierrez (USP).

56 Esta mesa instigante (e creio que bastante pioneira) foi coordenada por mim e recebeu como participantes: Stewart Hoover (University of Colorado), Leonildo Silveira Campos (UMESP), Susana Ramos Coutinho (Mackenzie), Gedeon Freire de Alencar (PUC-SP), 
a censura: "Du, se esta igreja está te censurando, pode ter certeza que você fez alguma coisa certa". Comentou ainda que nunca tinha escutado falar de uma igreja evangélica procurando censurar na Justiça uma obra acadêmica sobre ela.

Nosso evento foi encerrado com chave de ouro com a Conferência de Encerramento de Nicola Gasbarro (Universitá degli Studi di Udine), ${ }^{57}$ acompanhada de comentários de Adone Agnolin (USP). Nicola comentou, semelhantemente a Stewart, que nunca soube de episódios como este da tentativa de censura judicial na Europa e em qualquer outro lugar. Aliás, escutei a mesma coisa de Tim Jensen, Presidente da Associação Internacional de História das Religiões (IAHR). Tim também não se recordava, em conversa que tivemos em 2018, de episódios de censura de igrejas a livros científicos.

Cabe mencionar por fim, em relação às minhas memórias do dia 31 de outubro, que os trabalhos do evento foram fechados com o show do conjunto de classic rock Noise (creio que a única atividade do evento que não teve a ver com estudos de religiões e religiosidades), quando dei uma "palhinha" cantando músicas dos Beatles e Pearl Jam.

Jorge Miklos (UNIP), além de mim. Também havíamos recebido a confirmação da participação de Heidi Campbell (Texas University), mas a mesma adoeceu muito próximo ao evento (e não pôde participar à distância).

57 Intitulada $O$ monoteísmo e o fundamentalismo do pensamento, a conferência de Nicola foi publicada (pela Fonte Editorial, em 2013, em forma impressa; e pela Fogo Editorial, em 2019, em eBook), recebendo o seguinte resumo: "O pensamento antropológico e a prática política da modernidade destacam o "choque" de civilizações (Huntington) e o conflito interno destas (Nussbaum), caracterizados pelo valor da religião como um código fundamental do pensamento e da vida social. Se a estrutura da civilização está sujeita ao domínio do significado da religião, todos os outros códigos culturais das relações dos homens entre si (da política à lei, da economia à ética), e as relações dos homens com a natureza (da magia à ciência, da tecnologia à pesquisa) estão subordinados a, e/ou ordenados hierarquicamente por relações entre homens e deuses. Esta apresentação abordará as relações entre monoteísmo e fundamentalismo, ressaltando que o monoteismo é uma espécie de fundamentalismo do pensamento e da imaginação, daí a necessidade urgente de questionar historicamente a relação entre religião e política, monoteísmo e violência (texto traduzido por Adone Agnolin). (ABHR, Caderno de Programação..., 2013, p. 26). 
Imagem: Mesa Religiões e religiosidades no (do) ciberespaço, ${ }^{58}$ Conferência de Nicola Gasbarro (com participação de Adone Agnolin e minha); "palhinha» minha no show da banda Noise (classic rock) ${ }^{59}$

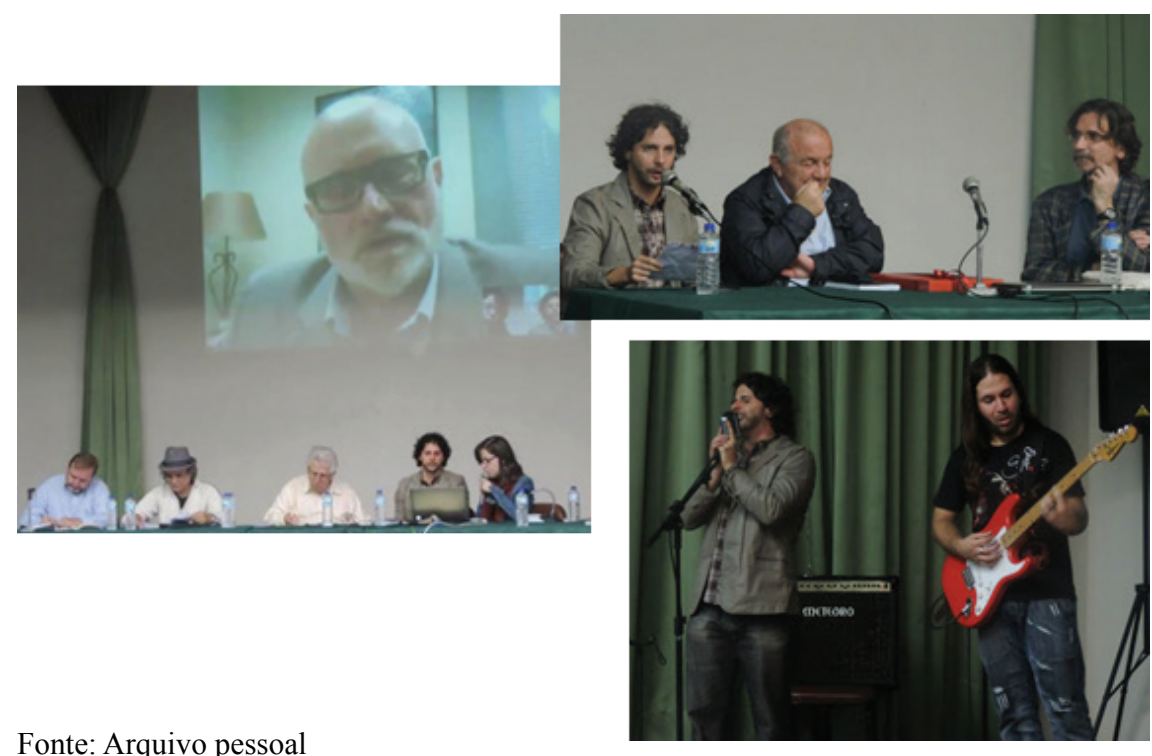

Sobre o evento, Celso Terzetti Filho contemplou que,

Nesses três dias de evento, pudemos observar e constatar como há uma grande produção de pesquisas sobre religião no Brasil. O Simpósio trouxe a oportunidade de estreitar os laços entre os pesquisadores, divulgar pesquisas e, principalmente, reforçar a busca pelo fortalecimento da importância do tema central do encontro. Neste sentido, acreditamos que o Simpósio da ABHR Sudeste e Internacional, sem dúvida, conseguirá se estabelecer como um dos eventos mais importantes da área. (TERZETTI FILHO, 2013, p. 195).

Para o autor, ficou um "gostinho de quero mais", certamente (com) partilhado por muitas pessoas participantes do evento: "Esperamos, com uma boa expectativa, que venha o próximo", dizia Celso. (TERZETTI FILHO, 2013, p. 195).

58 A participação de Stewart foi a única online do evento (bem a calhar para uma Mesa sobre ciberespaço). Todas as demais participações internacionais ocorreram "presencialmente".

$59 \mathrm{Na}$ foto, estou acompanhade do excelente guitarrista Ricardo Vital (Banda Noise). 
Terminado o evento, minhas lágrimas escorreram. Quantas dúvidas e incertezas minha alma cultivou naqueles tempos! Eu seria capaz de "tocar pra frente" um evento que eu não poderia solicitar financiamentos? As pessoas levariam a sério alguém que estava no doutorado na condução de um evento regional? E na organização geral de um simpósio internacional? Estaria eu a altura de palestrantes tão proeminentes como os que estiveram comigo na Mesa Religiões e religiosidades no (do) ciberespaço? Quem eu era academicamente para criar e conduzir tantas atividades? Para mediar uma conferência de abertura de Vagner e, ao lado de Adone Agnolin, uma conferência de encerramento de Nicola? Além disso, em re(l)ação à tensão provocada pela Bola de Neve Church, o que fazer naquele momento: lançar ou não o livro?

Bem, lancei o livro e procurei conduzir o evento da melhor forma que consegui. Fico particularmente feliz que a produção bibliográfica esteja corretamente publicada: Caderno de Programação e Resumos e Anais (ambos lançados durante o evento); livro impresso com dois volumes (o primeiro lançado durante o evento, o segundo no ano seguinte); livro do evento lançado e disponível gratuitamente em eBook (2019). ${ }^{60}$ Agora, quem lê o texto talvez esteja se (ou me) perguntando: além dos choros descritos acima, teria havido outra sequência de lágrimas por conta da censura? Houve sim, e como houve.

Como recebi ameaças anônimas, à época desenvolvi algo semelhante a uma síndrome do pânico. Fiquei com muito receio de sair sozinhe de casa e por meses só saia acompanhade de amigas em cuja presença eu me sentia segure. E por muitas vezes, chorei. ${ }^{61}$ Falar de censura em

\footnotetext{
60 Também em versão impressa, com tiragem reduzida (2019).

61 Sobre chorar em campo ou após o mesmo, recomendo, exemplarmente, trabalhos de Flávio Tavares (1999) e de Cristina Scheibbe Wolff (2013, 2015). Comentei acerca dos desafios de fazer um trabalho de campo, envolvendo subjetividades de quem pesquisa, anteriormente (2016), assim como fizeram muito antes Heloísa Pontes (1998), Joana Maria Pedro (2006), Temis Parente e Marina Ertzogue (2006), dentre outras pessoas. No meu caso, o choro vertido não foi por conta do que presenciei em campo, mas sim, pela censura após o trabalho de campo (ou seria um mergulho de campo / trabalho de praia pesquisar sobre uma igreja que tem (teve, na verdade) surfistas como público majoritário?); mais precisamente, após os relatos de pesquisa serem publicados no livro supracitado. Durante o doutorado, chorei por diversas outras vezes, mas em contextos distintos, de produção da pesquisa, quando observava ou escutava sobre as violências religiosas perpetradas a pessoas transgêneras por, por exemplo, ministérios de "cura, restauração e libertação" de gênero e sexualidade.
} 
2013 (ou antes disso, e também após) pode ser falar de sequelas, ou de uma espécie de choro que não congela. Quando alguém é pego por uma onda de intolerância, perseguição e censura, nem sempre sai ileso ou sem sofrer impactos emocionais ou de outra ordem.

Ao mesmo tempo, minha vontade de resistir era maior que o meu medo e que o choro (in) contido. Denunciei o caso, por exemplo, na Delegacia de Crimes de Racismo e Intolerância (DECRADI) de São Paulo e coloquei em meu perfil de Facebook que havia formalizado a denúncia e que ficaria de olho se ainda estivessem me intimidando. Meu medo de morrer era menor que a vontade de (sobre)viver. Vale notar que ainda resisto (re-existo?) em relação esta onda de censura. Tenho como intenção em 2020 relançar A grande onda vai te pegar em forma de eBook gratuito, com comentários acerca da violência cometida pela igreja em tela. E procurando me apoiar em Mário Quintana, penso que “eles passarão e eu passarinho". E passarinhando, vou fazendo meus trabalhos acadêmicos.

E penso ser necessário que falemos sobre toxicidade na universidade (ou na "univertoxicidade"), que por vezes mais aprisiona nossa subjetividade do que a libera, que mais aprisiona os saberes do que promove uma educação crítica, livre e emancipatória (como bem nos ensinava Paulo Freire). É preciso admitir o choro e não ficar (des)necessariamente segurando o mesmo, e é necessário que as pessoas não só estudem/pesquisem/ escrevam sobre afetos, emoções e sensibilidades como vivenciem estas coisas, já que somos mais que "pessoas acadêmicas": somos pessoas sensíveis, afetadas/afetuosas/afetivas. E sei que dizer isso não receberá a adesão de muitas pessoas: em diversos momentos percebi resistências de colegas a estes temas (emoções, afetos, sensibilidades), de modo semelhante à resistência que já sofreram temas como gênero/sexualidade e religiões na academia. Neste sentido, seriam atualmente os estudos de afetos os "novos estudos de gênero e de religião"?

\section{4}

Estava prevista a realização em 2014 do XIV Simpósio Nacional da ABHR em Curitiba (Paraná), sob o acolhimento da Universidade Federal do Paraná (UFPR) e PUC-Paraná, com o tema História: religião e revolução. Todavia, contingências alheias à $\mathrm{ABHR}$ fizeram com que o evento fosse cancelado, o que certamente despertou desapontamentos em muitas pessoas ávidas em participar desse importante encontro. A 
Direção Executiva então procuro viabilizar o evento em outra instituição, o Instituto Federal do Triângulo Mineiro (IFTM), de Uberaba (MG), de 18 a 20 de novembro. Mas a Comissão local não conseguiu organizá-lo em tempo. Então, a Direção da ABHR à época procurou realizá-lo em 2015. O evento seria realizado em Uberaba de 15 a 17 de abril, ${ }^{62}$ mas o mesmo também foi cancelado por motivos externos à vontade da Direção Executiva da ABHR. Com este cancelamento, a UFJF acolheu o evento em suas dependências, sem mudar data ou tema.

\section{5}

Entre 15 e 17 de abril de 2015 foi realizado o XIV Simpósio Nacional da ABHR, na UFJF (já tradicional em acolher eventos da Associação), com o tema Chico Xavier: mística e espiritualidade nas religiões brasileiras. Como observou Ítalo Domingos Santirocchi,

Tomando como emblema o médium espírita do Triângulo Mineiro, reconhecido nacionalmente, a proposta era discutir as diferentes espiritualidades presentes nas diversas religiões e formas de religiosidade no Brasil. Foi realizado com apoio da Universidade Federal de Juiz de Fora (UFJF) e organizado por professores do Programa de Pós-Graduação em Ciência das Religiões (PPCIR), sob a coordenação geral do prof. Arnaldo Érico Huff. (SANTIROCCHI, 2015, p. 119).

Ainda para Ítalo, "a quantidade de temas tratados nas comunicações foi enorme: divididas em 26 Grupos de Trabalhos (GT), participaram 264 comunicadores que puderam expor e discutir suas pesquisas, contando com a presença de cerca 500 pessoas no evento." (SANTIROCCHI, 2015, p. 119), número bastante expressivo de participantes que representaram a diversidade de assuntos içados:

Os GT se propuseram a discutir trabalhos sobre uma grande diversidade de religiões, tais como: cristãs, afro-brasileiras, espiritismo, indígenas e budismo, além das interconexões entre a religião e a arte, a política, o

62 O evento contaria com a organização do IFTM - Instituto Federal do Triângulo Mineiro (através do curso de Ciências Sociais e o mestrado em Educação); da UFTM - Universidade Federal do Triângulo Mineiro (curso de História); com o apoio da Fundação Cultural da Prefeitura de Uberaba; da Adhilac - Asociación de Historiadores Latinoamericanos y del Caribe, e do CEHAL - Centro de Estudos de História da América Latina (da Pontifícia Universidade Católica de São Paulo). Seria realizado em Uberaba (MG), nas dependências da Fachtus (Faculdade de Talentos Humanos), com o tema Chico Xavier, mística e espiritualidade nas religiões brasileiras. 
ensino, a sociedade, o espaço público, a filosofia, o patrimônio cultural, o gênero, o marketing, as relações internacionais, a ciência, a economia e o assistencialismo. Este sucinto elenco já permite vislumbrar a riqueza de discussões ocorridas durante o Simpósio. (SANTIROCCHI, 2015, p. 119).

\section{Durante o mesmo,}

foi realizada a Assembleia dos associados da ABHR. Nessa ocasião, a antiga diretoria composta pelos professores: Dr. Wellington Teodoro da Silva (PUC-MINAS) - Presidente, Dr. Vasni de Almeida (UFT) - Secretário Geral, Me. Daniel Rocha (UFMG) - Secretário de Divulgação e Dr. Ítalo Domingos Santirocchi (UFMA) - Tesouraria, encerrou sua gestão. Foram eleitos para nova diretoria executiva: Prof. Dr. Eduardo Meinberg de Albuquerque Maranhão Filho (USP) - Presidente; Profa. Dra. Patrícia Carla de Melo Martins (UNILAGO) - Secretária Geral; Prof. Me. Alfredo Bronzato da Costa Cruz (UERG) - Secretário de Divulgação e Prof. Me. Waldney de Souza Rodrigues Costa (UFJF) - Tesouraria. (SANTIROCCHI, 2015, p. 119).

Neste Simpósio participei relançando as obras de 2013, coordenando o GT Marketing, espetáculo e ciberespaço e ministrando Minicurso sobre o tema. Também mediei a Conferência sobre espiritismo proferida por Artur Cesar Isaia (que havia me coorientado no Mestrado). Durante o evento algumas pessoas me sondaram sobre meu interesse em presidir a ABHR. A primeira delas foi Diego Omar da Silveira, que comentou: "Du, estive conversando com a Mabel agora há pouco, e queríamos saber se você teria interesse em assumir a próxima Presidência da Associação, se você estaria disponível em ter seu nome sugerido na Assembleia Geral Ordinária". Confesso que ao escutar isso estremeci. Eu não havia até então sequer imaginado tal coisa. Lembro ter me sentido com vergonha e de algum modo constrangide - de modo algum por conta do tom utilizado por Diego, que foi sempre gentil comigo - mas pela ideia de presidenciar aquela que já na época era considerada uma das maiores associações de estudos de religiões da América Latina. Eu comentei com Diego que toparia sim, ainda que não soubesse se estaria à altura do desafio. Posteriormente, outras pessoas me fizeram a mesma pergunta. Durante a Assembleia, o Presidente Wellington questionou se alguém se habilitava a formar chapa para a Direção Executiva, e se haveriam indicações. Lembro que Patricia Carla se habilitou a formar a chapa, que Waldney fôra indicado por Arnaldo Huff Junior e Alfredo, por Leila Marrach Basto de Albuquerque (uma das sócias fundadoras da ABHR, aliás). O meu nome foi sugerido pelo até então Tesoureiro da Associação, Ítalo Santirocchi, e aprovado pela Assembleia, bem como os demais. 
Imagens: Momentos diversos com pessoas mais que especiais. ${ }^{63}$

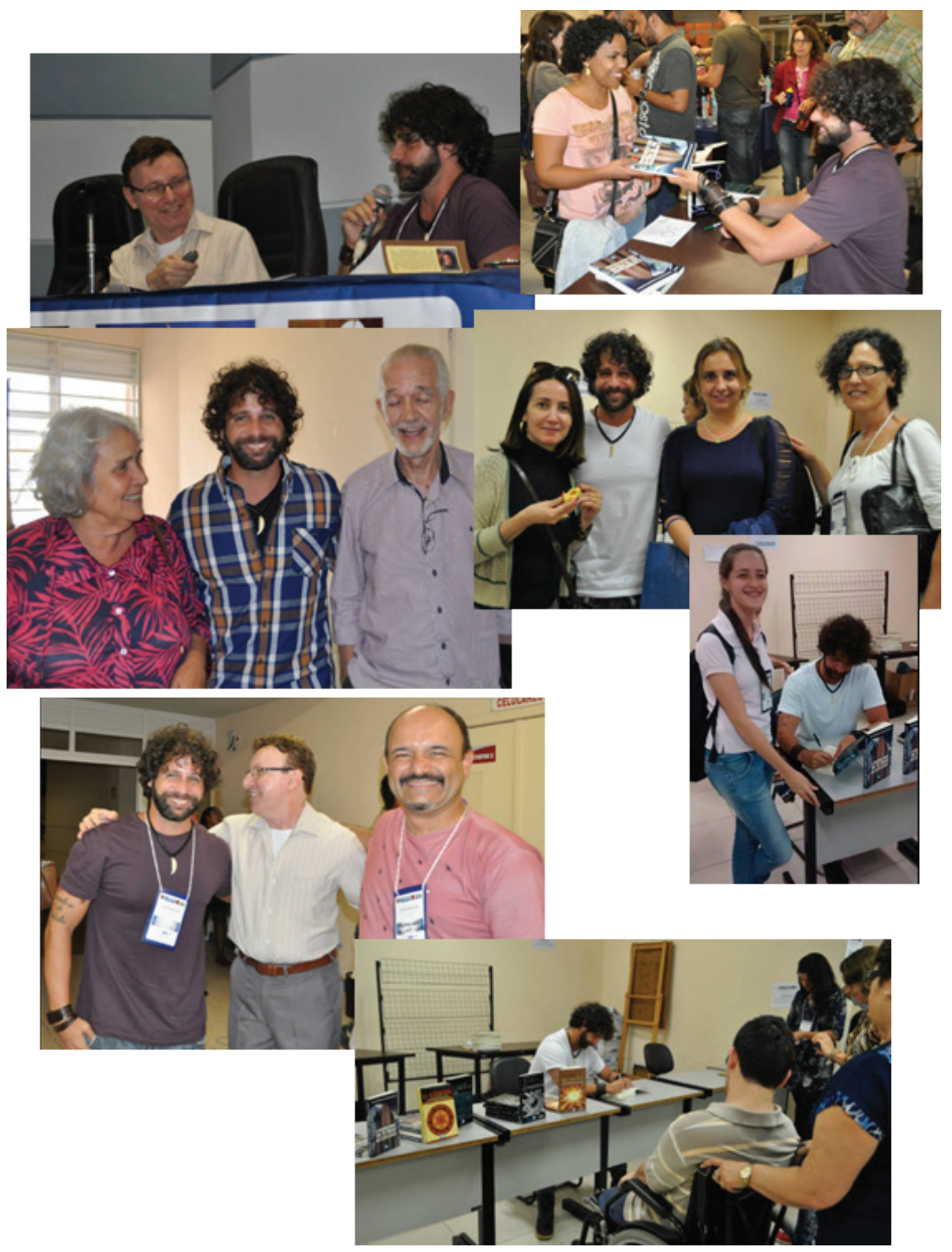

Fonte: Arquivo pessoal

63 Agradeço a cada uma destas pessoas pelos momentos de delicadeza, gentileza e trocas amorosas. Perdoem quem eu tiver esquecido de mencionar: Artur Cesar Isaia e Arnaldo Huff Junior; Jessie Jane Vieira de Souza e Zwinglio Motta Dias; Sandra Duarte de Souza, Patricia Carla Melo Martins e Naira Pinheiro; Leandro Faria Souza (e sua mãe Cléo). 
A oitava gestão da ABHR foi assim composta: fiquei na Presidência, Patrícia Carla de Melo Martins PUC/SP na Secretaria Geral, posteriormente substituída por Carlos André Macêdo Cavalcanti (UFPB), Alfredo Bronzato da Costa Cruz (UERJ), substituído no início da gestão por Ana Luíza Gouvêa Neto (UFJF), na Secretária de Divulgação, e Waldney de Souza Rodrigues Costa (UFJF) na Tesouraria. Agradeço pessoalmente a cada umx pelas contribuições de suma importância à ABHR. E peco desculpas por em muitos momentos "pecar" pelo perfeccionismo em relação a algumas atividades.

Durante a Assembleia Geral, realizada em 16 de abril de 2015, decidiu-se pela continuidade da regionalização. Dois coordenadores regionais foram escolhidos durante a reunião: Coordenação da Regional Norte: Diego Omar da Silveira (UEA) e Coordenação da Regional Centro-Oeste: Eduardo Gusmão de Quadros (PUC/GO). Outras três pessoas seriam escolhidas através de deliberação da Diretoria Executiva. Foram convidades Clarissa De Franco (PUC/SP) para a Coordenação da Regional Sudeste; Karla Regina Macena Pereira Patriota Bronsztein (UFPE) para a Coordenação da Regional Nordeste; e Rodrigo Toniol (UFRGS) para a Coordenação da Regional Sul.

Sugeri à nova Diretoria Executiva da ABHR que todos os Simpósios Regionais tivessem o mesmo tema gerador, acrescido de um subtema específico, a ser pensado juntamente com as Coordenações Regionais. ${ }^{64} \mathrm{O}$ tema gerador comum a todos os Simpósios Regionais, por sua vez, seria o mesmo do próximo Simpósio Nacional / Internacional. A esperança era de que as discussões fomentadas nos encontros regionais servissem de alicerce e arcabouço intelectual ativo nos debates do evento (inter)nacional.

Propus que o tema Gênero e Religião fosse selecionado para o II Simpósio Internacional da ABHR / XV Simpósio Nacional da ABHR, ${ }^{65}$ bem como para os Simpósios Regionais de 2015, por perceber um contexto contemporâneo marcado por misoginia e outras discriminações que envolvem identidades de gênero (como as transfobias) e orienta-

\footnotetext{
${ }^{64} \mathrm{E}$ que estes temas apontassem às especificidades e/ou estudos regionais, como já decidido em Assembleia Geral (2011).

65 Concomitantemente, realizamos o $3^{\circ}$ Simpósio Internacional da ABHR / $1^{\circ}$ Simpósio Sudeste da ABHR. Simpósio Regional Sul e o 2. Fazendo Arte Internacional da Associação.
} 
ções afetivas e sexuais (como a lesbofobia, a bifobia e a homofobia). A ABHR, como entidade acadêmica favorável à defesa de todos os tipos de Direitos Humanos, e contrária a quaisquer manifestações de intolerâncias e violações destes, objetiva, através do assunto principal dos seus próximos simpósios regionais e nacional, buscou adensar as discussões acerca do assunto, procurando contribuir positivamente para a igualdade entre todas/os cidadãs/ãos.

No segundo semestre de 2015 foram realizados dois Simpósios Regionais da ABHR:

a) $2^{\circ}$ Simpósio Nordeste da ABHR $-1^{\circ}$ Fazendo Arte da ABHR Nordeste, com o tema Gênero e religião - Diversidades e (in)tolerâncias nas mídias, na Universidade Federal do Pernambuco (UFPE), de 15 a 17 de setembro, e

b) $2^{\circ}$ Simpósio Sudeste da ABHR $-2^{\circ}$ Fazendo Arte da ABHR Sudeste, com o tema Gênero e religião - Violência, fundamentalismos e política, realizado na Pontifícia Universidade Católica de São Paulo (PUC/SP), entre 25 a 27 de novembro de 2015. ${ }^{66}$

Os eventos tiveram o mesmo tema gerador, com o fito de prepararem e adensarem discussões a serem efetivadas no próximo Simpósio Internacional / Nacional (2016). Entendemos na época (e continuo compreendendo da mesma forma) que a temática desses encontros eram (são), mais que oportunas, necessárias. A ABHR - de sua gênese até 2019 - demonstrou posição firme e consolidada a respeito: é uma Associação que repudia veementemente toda e qualquer discriminação e preconceito, e procura atuar consistentemente, não só no alargamento e refino dos estudos de religiões e religiosidades em território nacional, como na preservação da democracia e da cidadania.

As Coordenadoras dos Simpósios Nordeste e Sudeste (eu atuei na co-coordenação de ambos), Karla Regina Bronzstein e Clarissa De Franco, em meio a muitas dificuldades econômicas e alguns entraves burocráticos (houve pessoas do campo de Ciências das Religiões que

${ }_{66}$ Por contingências alheias à vontade da Diretoria Executiva da ABHR, em 2015 não foram realizados os Simpósios Regionais Norte, Centro-Oeste e Sul. 
"torceram o nariz" para o tema destes eventos), foram exemplares e excepcionais na liderança destes eventos. Os relevantíssimos livros destes Simpósios, organizados por ambas e por mim, foram publicados em forma de eBook, sendo disponibilizados gratuitamente. ${ }^{67}$

Durante o $2^{\circ}$ Simpósio Nordeste da ABHR realizamos Assembleia Geral Extraordinária, ${ }^{68}$ convocada de acordo com as exigências de nosso Estatuto Social, em que foram aprovadas algumas inovações que sugeri para a Associação: criação da Comissão de Direitos Humanos da ABHR; do Prêmio ABHR de Teses, Dissertações e TCCs (em níveis nacional e regional); da ABHRinha (atividades lúdicas para crianças e adolescentes de estímulo à cidadania e respeito à diversidade religiosa e demais diversidades); da filiação de Programas de Pós, Núcleos e Grupos de Pesquisa (dentre outras entidades interessadas); da categoria Pessoa Associada Colaboradora (isenta de anuidade); de um novo logotipo (a ser desenvolvido pela artista Laerte Coutinho); do Fórum Social da ABHR (momento de diálogos sobre a situação política do país); de sites e páginas de Facebook de todas as regionais; dos Cadernos Regionais (para produção bibliográfica específica). ${ }^{69}$ Também notei a precisão da continuidade do Fazendo Arte da ABHR e do Prêmio ABHR de Pôsteres (que propus em 2013). Todas as sugestões foram aprovadas pela Assembleia.

Tais novidades refletiam as preocupações da ABHR em auxiliar no provimento de reflexões propositivas de alargamento democrático das pesquisas sobre o fenômeno religioso, e de ações de combate pacífico e profícuo às intolerâncias e às violações de conquistas sociais, direitos constitucionais e Direitos Humanos.

\footnotetext{
67 Acesse: www.amarfogo.com (eBooks).

68 A Assembleia foi realizada na UNICAP no dia 14 de setembro de 2015, após um belo Pré-Evento (organizado lindamente por Karla) em que visitamos diversos locais de devoção religiosa de Recife.

69 Também lembrei a necessidade de elaboração de Boletim Informativo Eletrônico, como previsto em Atas de eventos anteriores.
} 
Imagens: à esquerda, logotipo da $\mathrm{ABHR}$, feito pela cartunista Laerte Coutinho, e à direita, o também bonito logotipo da ABHR utilizado até então
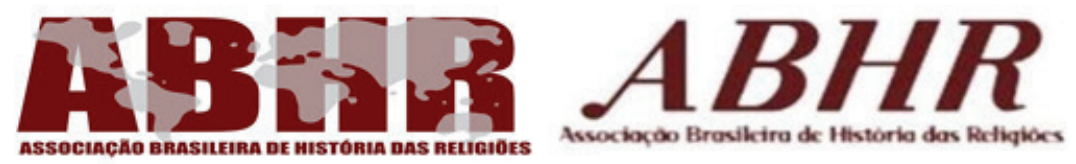

Fonte: Arquivo pessoal

Muitas das atividades aprovadas na Assembleia foram realizadas no próprio Simpósio da ABHR Nordeste, como a nossa primeira ABHRinha, que teve a participação exatamente de 100 crianças e adolescentes, a maioria alunes do Colégio de Aplicação da UFPE.

Durante o primeiro Fórum Social da $\mathrm{ABHR}^{70}$ foram aprovadas diversas moções de repúdio (o que veio a se tornar usual nos eventos posteriores), como a Moção de repúdio aos atos de destruição dos terreiros de candomblé das cidades de Santo Antônio do Descoberto, Águas Lindas de Goiás-GO e Valparaíso de Goiás-GO, e a Moção de Repúdio à exclusão dos termos "população de terreiros", "gênero" e "diversidade" do Plano Municipal de Educação (PME), de Picos-PI. ${ }^{71}$ Também foi fundado o coletivo acadêmico independente Evangélicas pela Igualdade de Gênero (IEG).

Se no primeiro Simpósio Internacional / primeiro Simpósio Sudeste da ABHR a hostess foi Tchaka Drag Queen, no segundo Simpósio Nordeste a hostess foi Luanddha Peron, a primeira pastora drag queen do Brasil (pastora da Igreja da Comunidade Metropolitana - ICM - do Rio de Janeiro). ${ }^{72}$

70 Realizado em 17 de setembro de 2015.

71 Sendo ambas apresentadas por pessoas associadas, as moções foram lidas logo após a Conferência de Encerramento do evento, proferida por Durval Muniz de Albuquerque Junior (UFRN), em 17 de setembro de 2015.

72 O pedagogo e pastor Marcos Lord, concomitantemente Luanddha Perón, é uma das pessoas que colaboraram na carpintaria de minha Tese de Doutorado em História Social: (Re/des) conectando gênero e religião: Peregrinações e conversões trans* e ex-trans* em narrativas orais e do Facebook (2014). 
Imagens: Instantes afetuosos com pessoas incríveis. ${ }^{73}$

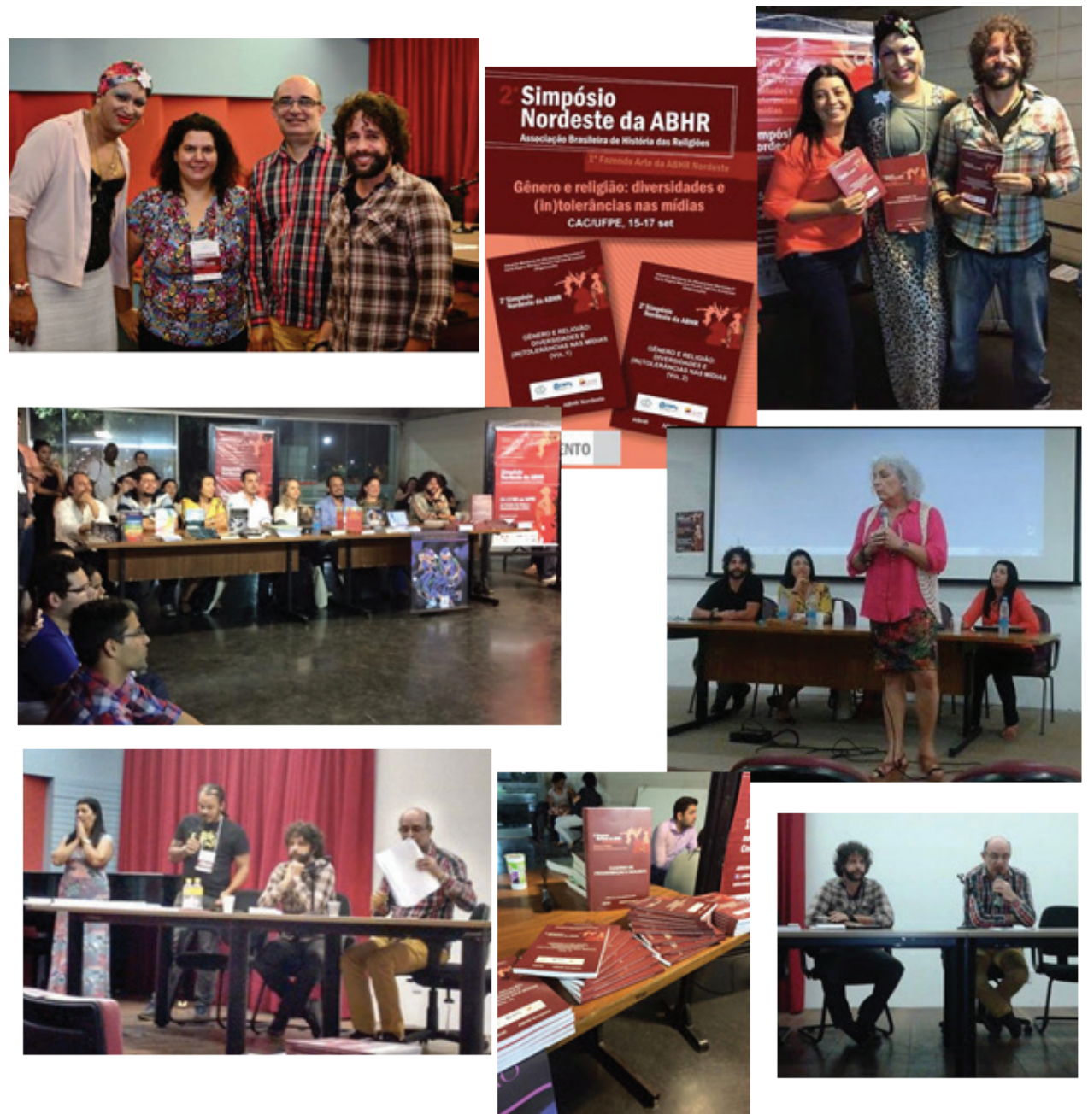

Fonte: Arquivo pessoal

73 Divulgação de Facebook dos dois volumes do livro do $2^{\circ}$ Simpósio Nordeste da ABHR; Karla Regina Bronzstein, Luanddha Peron e eu, lançando a produção bibliográfica do evento: Caderno de Programação e Resumos ("Tamanho Família”) e os dois volumes impressos do livro do evento; leitura de Moção de Repúdio apresentada por Paulo Mafra, antes da Conferência de Encerramento de Durval Muniz de Albuquerque Junior; Mesa Redonda com Christina Vital da Cunha, Leticia Lanz e Karla; Edlaine Gomes com Luanddha, Durval e eu; lançamento de livros. Gratidão a todas estas pessoas magníficas com quem (dentre muitas outras) realizei trocas sensíveis no evento. 
O Simpósio Sudeste foi igualmente um sucesso - ainda que tenhamos recebido alguma resistência por parte de uma ou outra pessoa que pesquisam religiões e religiosidades mas que compreendiam à época que temas como o do evento não eram suficientemente caros à pesquisa científica. Mas Clarissa De Franco (assim como Karla Patriota em relação à ABHR Nordeste) conduziu o evento com coração delicado e nervos de aço: um exemplo a ser seguido.

Imagens: cartaz de divulgação do $2^{\circ}$ Simpósio Sudeste da ABHR;

Capas de Livros dos Simpósios Regionais da ABHR (2015)

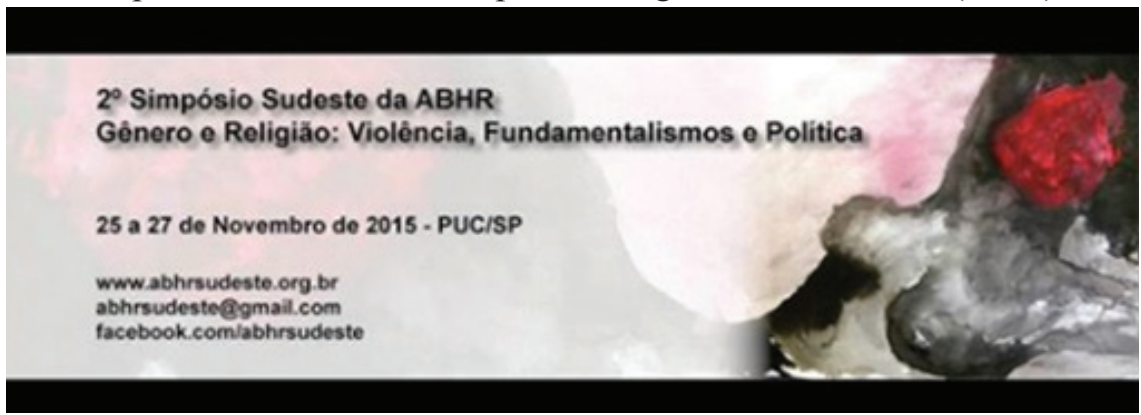

Fonte: Arquivo pessoal

Imagens: Capas de Livros dos Simpósios Regionais da ABHR (2015)
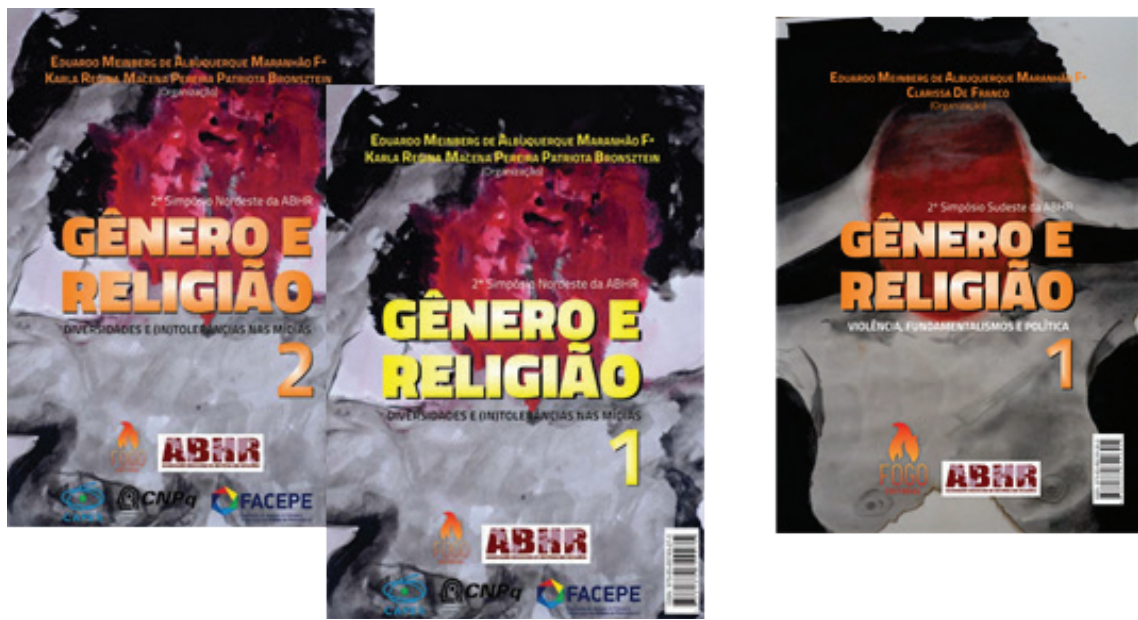

Fontes: www.amarfogo.com e www.fogoeditorial.com.br 
Outra ação da ABHR em 2015 esteve na confecção de cartas contra violências e intolerâncias, como a Carta da ABHR em apoio aos/às professores/as paranaenses, de 1 o de maio de 2015 , escrita por conta da violência praticada pelo governo do Paraná a docentes. ${ }^{74}$

Neste $1^{\circ}$ de maio de 2015, dia consagrado aos/às trabalhadores/as do mundo inteiro, e dentre eles/as os professores e as professoras brasileiros/as, é com pesar que nos defrontamos com uma situação que atingiu violenta e frontalmente não somente os/as educadores/as paranaenses como todos e todas educadores e educadoras do país.

Em 29 de abril, aproximadamente 15 mil professores e professoras, além de estudantes e servidores/as públicos/as, exerciam seu direito constitucional de manifestação e greve nas proximidades da Assembleia Legislativa de Curitiba, Paraná. As manifestações, legítimas, eram de protesto contra a votação em curso de um projeto do governador Beto Richa (PSDB), que reduzia os repasses do governo para pensionistas e transferiria inativos de fundos previdenciários, afetando potencialmente pensionistas e servidores/ as estaduais no decorrer dos próximos anos.

Durante a manifestação, um contingente de cerca de 1,5 mil soldados da Polícia Militar (PM), amparado por tropas de choque e de elite, foi acionado para coibir a manifestação de professores/as, estudantes e servidores/ as. O continente militar referido, atuando com forca desproporcional e truculência, como noticiaram diversa veículos da mídia, incidiram contra os/as manifestantes com jatos de água, cassetetes, balas de borracha, bombas de gás e cães treinados. Como noticiado, a operação militar legou um saldo de mais de 200 pessoas feridas (muitas ainda hospitalizadas), entre uma ampla maioria de professores e professoras, mas também estudantes e servidores/as públicos/as.

A ABHR - Associação Brasileira de História das Religiões, entidade acadêmica representativa de professores/as e pesquisadores/as acadêmicos/ as de religiões e religiosidades em nosso país, vêm através desta carta demonstrar seu apoio e solidariedade aos/às professores/as paranaenses e repudiar as atitudes violentas perpetradas, que, mais que atingir os/as educadores/as paranaenses, violam direitos constitucionais e legítimos de manifestação e atentam contra a Educação brasileira como um todo.

Esta carta representou a primeira ação pública da Gestão 201517. E outras cartas se seguiram a esta. Em 25 de julho de 2015, data

74 Algumas das Cartas Abertas e Moções da ABHR ainda podem ser acessadas através do sítio original da Associação, em www.abhr/abhr/cartas-da-abhr. Parte do conteúdo do site, quando este foi invadido (em meados de 2019) foi alterado, mas esta parte está (até início de 2020), íntegra. 
de aniversário de 16 anos da ABHR, propus lançarmos a Carta da ABHR em repúdio à intolerância religiosa e demais intolerâncias, que confeccionei:

Neste 25 de junho de 2015, data em que a Associação Brasileira de História das Religiões (ABHR), entidade acadêmica não-confessional e apartidária, completa 16 anos de atuação que deveriam ser festejados com alegria, nossos sentimentos se encontram na iminência do luto.

Este intenso pesar se deve à crescente onda de intolerância, reacionarismo e fundamentalismo que vem assolando o Brasil e aviltando a concepção de sociedade plural, relacionada a múltiplos episódios de violência simbólica e física a pessoas de diferentes expressões religiosas, especialmente de religiões de matriz afro-brasileira e do espiritismo kardecista, e também a pessoas sem-religião, ateias e agnósticas. Devemos recordar que a liberdade de crença é um direito fundamental assegurado pela Declaração Universal dos Direitos Humanos e por nossa Constituição:

"Toda pessoa tem o direito à liberdade de pensamento, consciência e religião; este direito inclui a liberdade de mudar de religião ou crença e a liberdade de manifestar essa religião ou crença, pelo ensino, pela prática, pelo culto e pela observância, isolada ou coletivamente, em público ou em particular". (DECLARAÇÃO UNIVERSAL DOS DIREITOS HUMANOS, 1948). "Todos são iguais perante a lei, sem distinção de qualquer natureza [...] é inviolável a liberdade de consciência e de crença, sendo assegurado o livre exercício dos cultos religiosos e garantida, na forma da lei, a proteção aos locais de culto e a suas liturgias". (CONSTITUIÇÃO DA REPÚBLICA FEDERATIVA DO BRASIL,1988).

Além de manifestações de intolerância religiosa, desdobram-se uma multiplicidade de violações igualmente execráveis aos Direitos Humanos e constitucionais, por conta de marcadores sociais distintos, como sexismo, misoginia, machismo, androcentrismo, capacitismo, racismo, colorismo, etnocentrismo, elitismo, lesbofobia, transfobia, homofobia, bifobia, etarismo, xenofobia, discriminação socioeconômica e de procedência regional, dentre uma miríade de outras, muitas vezes amalgamadas. A intolerância pode ser interseccional: o fundamentalismo religioso entrecruza com o de gênero, o étnico, o de orientação afetiva, dentre outras equações. Assim, nos solidarizamos com todas e todos que vêm sofrendo discriminações devido às suas escolhas religiosas ou a-religiosas, orientações afetivas e/ou sexuais, identidades de gênero, raças, cores, aparências, origens, limitações e necessidades especiais, ou por outros motivos. No mesmo contexto, preocupa-nos o fomento, no Congresso

Nacional e em um contexto de laicidade, de pautas supostamente fundamentadas em pressupostos religiosos e que pretendem barrar avanços 
de minorias políticas, deslegitimando a diversidade do tecido social. O Brasil é um país caracterizado pela multiplicidade de formas de existir: todas/os cidadãs e cidadãos devem ter os mesmos direitos e deveres, independentemente de suas religiões e de outros marcadores identitários.

A ABHR tem promovido discussões sobre política, religião e violações dos Direitos Humanos. Em 2013, na USP, realizamos um Simpósio Internacional / Regional que teve como tema as Diversidades e (In)Tolerâncias Religiosas. Neste ano, temos prevista a realização de Simpósios Regionais que tem Gênero e Religião como tema gerador, relacionado às pluralidades e discriminações. O primeiro será realizado na UFPE em setembro. Simultaneamente, ofereceremos atividades direcionadas aos públicos infantil e adolescente. Sabemos que isto não é suficiente e que são necessárias atitudes mais propositivas. Convidamos todas e todos para que participem das discussões destes e de outros fóruns, e que pensemos juntas/os em formas proativas de atuação contra todas as formas de intolerâncias. Acreditemos na Educação: se uma pessoa aprende a odiar e ser intolerante, também pode aprender a respeitar.

A ABHR demonstra seu apoio e solidariedade a quem sofre intolerância religiosa ou por conta de outros marcadores sociais, de modo interseccional ou não. A ABHR apresenta seu veemente repúdio em relação a qualquer forma de intolerância, fundamentalismo e discriminação. Entendemos que tais práticas violam direitos constitucionais e legítimos de cidadania e atentam contra os Direitos Humanos em sua forma mais ampla. Sentimo-nos próximos ao luto, mas, ainda não enlutados, lutemos - sempre pacificamente, através de ideias e atitudes proficientes. A ABHR assume aqui seu papel de colaboradora nas reflexões e na preservação da democracia, cidadania, sociedade plural e diversidade humana, que se encontram em risco de falência (ABHR, 2015). ${ }^{75}$

Em 2015 procurei os dirigentes de outras associações propondo-lhes parcerias e trabalhos conjuntos como a organização de eventos futuros, além da elaboração de carta conjunta com o mesmo tema acima. Tratou-se da Carta Aberta Coletiva em Repúdio à Intolerância Religiosa, co-assinada em julho de 2015:

2015 tem sido marcado por inúmeras manifestações de intolerância religiosa, especialmente em relação a pessoas fiéis de religiões de matriz

75 Ver: Anais do $3^{\circ}$ Simpósio Nordeste da ABHR - Religião, Direitos Humanos e Laicidade; Resistências, Diversidades e Sensibilidades (MARANHÃO F., 2020). Em: www. amarfogo.com (eBooks). 
afro-brasileira. Em resposta a tais ataques, em junho deste ano foram lançadas duas cartas de repúdio, uma assinada pela Associação Brasileira de Antropologia (ABA), e intitulada Nota da ABA em repúdio aos recentes atos de violência contra adeptos das religiões afro-brasileiras, e outra, pela Associação Brasileira de História das Religiões (ABHR), denominada Carta da $\mathrm{ABHR}$ em repúdio à intolerância religiosa e demais intolerâncias, demonstrando a mobilização de entidades acadêmicas em relação ao assunto. Entendemos que mobilizações como estas, necessárias, devem servir para adensar as reflexões acerca do tema e, mais que isto, serem agregadas de atitudes propositivas. É preciso pensarmos em um programa de ações que promova o entendimento e o respeito entre pessoas de diferentes religiões e quaisquer outros pertencimentos, e é neste sentido que as entidades signatárias desta Carta procuram estimular não somente nossos pares na academia como toda a sociedade civil a avaliar formas de preservação e ampliação dos direitos de cidadãs e de cidadãos de todo o País. Mais do que simples tolerância, necessitamos desenvolver atitudes que levem as pessoas a apreciarem, respeitarem e valorizarem quem é diferente de si, como um projeto inventivo para uma nova ética.

As entidades que assinam esta Carta repudiam publicamente todos os tipos de manifestações de intolerância religiosa, se solidarizam com as pessoas discriminadas, de quaisquer religiões, e encorajam que pensemos todos/as juntos/as em atitudes profícuas no combate pacífico às violações dos direitos de crença (e descrença) de todos/as brasileiros/as, bem como outras formas de discriminações.

Associação Brasileira de Antropologia (ABA) / Associação Brasileira de História das Religiões (ABHR) / Associação de Cientistas Sociais de Religião do Mercosul (ACSRM) / Associação Nacional de Pós-graduação e Pesquisa em Teologia e Ciências da Religião (ANPTECRE) / ANPUH Associação Nacional de História (ANPUH) / Grupo de Trabalho História das Religiões e Religiosidades da ANPUH (GTHRR/ANPUH) / Instituto de Estudos de Religião (ISER) / Sociedade de Teologia e Ciências da Religião (SOTER) (2015).

Estes são exemplos de cartas que foram publicadas pelas gestões 2015-2017 e 2017-2019: outras foram lançadas mas não estão referidas neste artigo que, lamentavelmente, não dá conta da extensão das ações da ABHR nestas gestões.

De todo modo, é importante dar realce: que belos trabalhos a ABHR tem realizado! Estamos todes de parabéns - desde as Comissões Organizadoras e Científicas de nossas atividades como as pessoas que 
participaram das mesmas e aquelas que administra(ra)m a Associação. Temos motivos para nos emocionar sensivelmente e comemorar!

"Fechando os trabalhos" deste primeiro texto, peço a licença para apresentar as capas dos livros da ABHR referentes aos Simpósios Internacionais e Regionais que coordenei na mesma - e convido a todes que me lêem a baixarem gratuitamente estes belos legados. Estas obras foram publicadas entre 2018 e 2020 pela Fogo Editorial, e no mesmo sítio estão disponíveis os Anais do $3^{\circ}$ Simpósio Nordeste da ABHR. Os trabalhos, disponíveis em acesso livre e aberto, encontram-se em: www.amarfogo.com e www.fogoeditorial.com.br. ${ }^{76}$

Ainda serão publicados em 2020 o volume referente ao $3^{\circ}$ Simpósio Sul dia Associação (Educação e respeito às diversidades), o $2^{\circ}$ volume do $3^{\circ}$ Simpósio Internacional / XVI Nacional de 2018 (Política, Religião e Diversidades: Educação e Espaço Público), todos a serem disponibilizados gratuitamente no site da Fogo Editorial (sem ônus para a ABHR).

Destaco, ainda, que também será lançada em eBook, em 2020, a belíssima Dissertação de Mestrado de Fernanda Coelho, orientada por Sandra Duarte de Souza (UMESP), e premiada em Primeiro Lugar no Primeiro Prêmio ABHR Nacional de Teses, Dissertações e TCCs, que idealizei em 2015. O trabalho de Fernanda, intitulado "Menino já nasce menino, menina já nasce menina": fobia religiosa de gênero e suas implicações no debate sobre o Plano Nacional de Educação Brasileiro no periodo de 2012 - 2014, foi premiada durante nosso $3^{\circ}$ Simpósio Internacional / XVI Nacional de 2018 (Política, Religião e Diversidades: Educação e Espaço Público), recebendo Nota 10 de todes pareceristas. A mesma será publicada pela Fogo Editorial e disponibilizada gratuitamente em seu sítio (acima mencionado).

Por fim, recordo que este texto cobre os dois primeiros anos de internacionalização e regionalização da ABHR (2013 a 2015), e que ele se desdobra em um outro artigo (que não só convido como solicito humildemente a leitura). $\mathrm{O}$ nome do próximo texto é Memórias sensiveis em caleidoscópio: A internacionalização e a regionalização da Associação

76 Todos os livros dos Simpósios da ABHR acima referidos foram produzidos generosamente pela Fogo Editorial, sem nenhum ônus à ABHR. Não foi utilizado nenhum recurso de caixa vindo de Simpósios, tampouco da ABHR. 
Brasileira de História das Religiões (ABHR) entre 2016 e 2019, tendo sido publicado na Revista Plura (Dossiê 20 Anos da ABHR). Que a ABHR continue sendo esta entidade autônoma, democrática, aberta, provocadora do senso crítico e dinâmica em defesa da laicidade, dos melhores ideais democráticos e de uma educação que respeita as diversidades! ${ }^{77}$

Seguem links para acesso a estas obras:

- Religião, Direitos Humanos e laicidade: Resistência, diversidades e sensibilidades $-3^{\circ}$ Simpósio Nordeste da ABHR, 2019) Baixe aqui gratuitamente

- Política, religião e diversidades: Educação e espaço público $3^{\circ}$ Simpósio Internacional da ABHR / XVI Simpósio Nacional da ABHR (2018) Baixe aqui gratuitamente

- Diversidades e (in)tolerâncias religiosas (Vol. 1) - $1^{\circ}$ Simpósio Internacional da ABHR / I Simpósio Sudeste da ABHR (2019) Baixe aqui gratuitamente

- Diversidades e (in)tolerâncias religiosas (Vol. 2) - $1^{\circ}$ Simpósio Internacional da ABHR / I Simpósio Sudeste da ABHR (2019) Baixe aqui gratuitamente

- Gênero e religião: Diversidades e (in)tolerâncias nas mídias (Vol. 1) - $2^{\circ}$ Simpósio Nordeste da ABHR (2019) Baixe aqui gratuitamente

- Gênero e religião: Diversidades e (in)tolerâncias nas mídias (Vol. 2) - $2^{\circ}$ Simpósio Nordeste da ABHR (2019 Baixe aqui gratuitamente

- Gênero e religião: Violência, fundamentalismos e política (Vol. 1) $-2^{\circ}$ Simpósio Sudeste da ABHR (2019) Baixe aqui gratuitamente

- História, gênero e religião: Violências e Direitos Humanos (Vol. 1) - $2^{\circ}$ Simpósio Internacional da ABHR / XV Simpósio Nacional da ABHR - II Simpósio Sul da ABHR (2018) Baixe aqui gratuitamente

- História, gênero e religião: Violências e Direitos Humanos (Vol. 2) - $2^{\circ}$ Simpósio Internacional da ABHR / XV Simpósio Nacional da ABHR - $2^{\circ}$ Simpósio Sul da ABHR (2018) Baixe aqui gratuitamente

Utilizei as mesmas referências ao final do trabalho nos dois textos, visto serem ambos complementares. 
Afetos e memórias em mosaico: A Associação Brasileira de História das Religiões (ABHR) 205 em sua regionalização e internacionalização (2013 a 2015)

Imagens: Capas de Livros de Simpósios da ABHR (2013-2019)

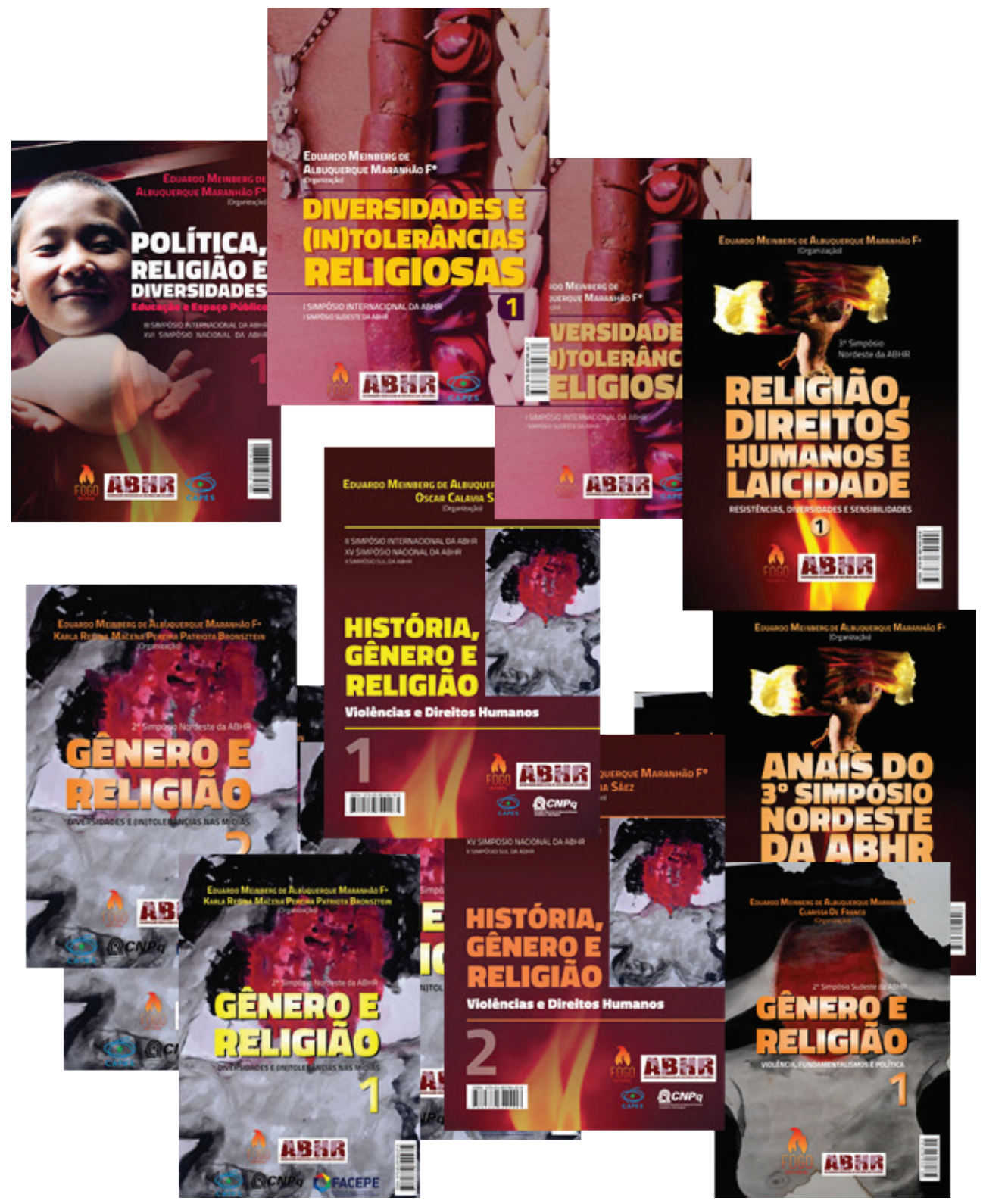

Fontes: www.amarfogo.com e www.fogoeditorial.com.br 


\section{Referências Bibliográficas}

XIV SIMPÓSIO Nacional da Associação Brasileira de História das Religiões, 14., 2015, Juiz de Fora. Chico Xavier: mística e espiritualidade nas religiões brasileiras. Caderno de Resumos. Juiz de Fora: UFJF, 2015. p.139-140.

AÇÃO EDUCATIVA (Org.). A ideologia do movimento Escola Sem Partido: 20 autores desmontam o discurso. São Paulo: Ação Educativa, 2016, p. 49-58.

ALMEIDA, Vasni. A parceria com a Editora Paulinas: experiências de publicações na ABHR. In: MARANHÃO F ${ }^{\circ}$, Eduardo Meinberg de Albuquerque. (Org.). Política, religião e diversidades: Educação e espaço público (Vol. 2) - II Simpósio Internacional da ABHR / XVI Simpósio Nacional da ABHR. Florianópolis: ABHR / Fogo Editorial, 2020.

BOBSIN, Oneide; SCHAPER, Valério Guilherme; REBLIN, Iuri Andréas. Cartografias do sagrado e do profano: religião, espaço e fronteira (Orgs.). Anais do $1^{\circ}$ Simpósio Sul da Associação Brasileira de História das Religiões (ABHR). São Leopoldo, 2014.

CARVALHO, Sarita dos Santos. A continuidade do diálogo nos Simpósios-2016 da Associação Brasileira de História das Religiões. Reflexão, Campinas, 41(2):259-265, jul./dez., 2016.

ENGLER, Steven. Brazil. The emergence and development of the study of religions. In: ALLES, Gregory D. Religious Studies: a global view. London and New York: Routledge, 2018.

FRANCO, Clarissa De; MARANHÃO Fº Eduardo Meinberg de Albuquerque. O Brasil terrivelmente cristão, bélico e privatista da ideologia de gênesis: os ataques do Governo Bolsonaro à educação e à pluralidade. Mandrágora. No prelo (a). vatizador: a opressão à educação em direitos humanos no governo Bolsonaro. Revista de Estudos Teológicos. No prelo (b).

FRANK, Robert. Questões para as Fontes do Presente. In: CHAVEAU, A.; TÉTART, P. (Orgs.). Questões para a história do presente. Bauru/SP: EDUSC, 1999.

HALBWACHS, Maurice. A memória coletiva. São Paulo: Vértice, Editora Revista dos Tribunais, 1990.

HUFF JÚNIOR, Arnaldo Érico. Campo religioso brasileiro e História do Tempo Presente - Anais do II Encontro Nacional do GT História das Religiões e das Religiosidades. Revista Brasileira de História das Religiões. São Paulo, v. 1, n. 3, 2009. p. 20. 
LARROSA, Jorge. A operação ensaio. Sobre o ensaiar e o ensaiar-se no pensamento, na escrita e na vida. Educação \& Realidade. Dossiê Michel Foucault, Porto Alegre, v. 29, n.1, p. 27-43, 2004.

MARANHÃO $\mathrm{F}^{\circ}$, Eduardo Meinberg de Albuquerque. A grande onda vai te pegar: Marketing, espetáculo e ciberespaço na Bola de Neve Church. São Paulo: Fonte Editorial, 2013.

(Org.). Diversidades e (In)Tolerâncias Religiosas. Anais do $\mathbf{1}^{\circ}$ Simpósio Sudeste / $1^{\circ}$ Simpósio Internacional da Associação Brasileira de História das Religiões (ABHR). São Paulo, 2013.

(Org.). Religião, Direitos Humanos e laicidade: Resistência, diversidades e sensibilidades. Anais do $3^{\circ}$ Simpósio Nordeste da ABHR. Florianópolis: ABHR / Fogo Editorial, 2019.

. "A travesti morreu, mas carrego ela no caixão" e outras histórias vivas: conversão, transfobia religiosa e morte. Revista Brasileira de História das Religiões, v. 10, n. 9, p. 165-216, 2017.

; SENE, Talita. Caderno de Programação e Resumos do $1^{\circ}$ Simpósio Internacional da ABHR / $1^{\circ}$ Simpósio Sudeste da ABHR: Diversidades e (In)Tolerâncias Religiosas. São Paulo: ABHR, 2013. Disponível em: https://independent.academia.edu/DuMeinbergMaranhão

(Org.). Diversidades e (in)tolerâncias religiosas (Vol. 1) $-1^{\circ}$ Simpósio Internacional da ABHR / I Simpósio Sudeste da ABHR. Florianópolis: ABHR / Fogo Editorial, 2019.

(Org.). Diversidades e (in)tolerâncias religiosas (Vol. 2) $-1^{\circ}$ Simpósio Internacional da ABHR / I Simpósio Sudeste da ABHR Florianópolis: ABHR / Fogo Editorial, 2019.

; COELHO, Fernanda Marina Feitosa; DIAS, Tainah Biela. "Fake news acima de tudo, fake news acima de todos": Bolsonaro e o "kit gay", "ideologia de gênero" e fim da "família tradicional". Correlatio, v. 17, n. 2, p. 65-90, 2018.

; BRONZSTEIN, Karla Regina Macena Patriota (Orgs.). Gênero e religião: Diversidades e (in)tolerâncias nas mídias (Vol. 1) - $2^{\circ}$ Simpósio Nordeste da ABHR Florianópolis: ABHR / Fogo Editorial, 2019.

; BRONZSTEIN, Karla Regina Macena Patriota (Org.). Gênero e religião: Diversidades e (in)tolerâncias nas mídias (Vol. 2) - $2^{\circ}$ Simpósio Nordeste da ABHR Florianópolis: ABHR / Fogo Editorial, 2019.

; FRANCO, Clarissa de (Orgs.). Gênero e religião: Violência, fundamentalismos e política (Vol. 1) $2^{\circ}$ Simpósio Sudeste da ABHR Florianópolis: ABHR / Fogo Editorial, 2019. 
; SÁEZ, Oscar Calavia (Orgs.). História, gênero e religião: Violências e Direitos Humanos (Vol. 1) $2^{\circ}$ Simpósio Internacional da ABHR / XV Simpósio Nacional da ABHR - II Simpósio Sul da ABHR Florianópolis: ABHR / Fogo Editorial, 2018.

; SÁEZ, Oscar Calavia (Orgs.). História, gênero e religião: Violências e Direitos Humanos (Vol. 2) $2^{\circ}$ Simpósio Internacional da ABHR / XV Simpósio Nacional da ABHR - $2^{\circ}$ Simpósio Sul da ABHR Florianópolis: ABHR / Fogo Editorial, 2018.

. "Matando uma leoa por dia": ideologia de gênero e de gênesis na "cura" de travestis. Correlatio, v.17, n.2, p.107-148, 2018.

. Memórias sensíveis em caleidoscópio: A internacionalização e a regionalização da Associação Brasileira de História das Religiões entre 2016 e 2019. PLURA, Revista de Estudos de Religião, vol. 10, nº 2, 2019, p. $49-101$.

; FRANCO, Clarissa De. "Menino veste azul e menina, rosa" na Educação Domiciliar de Damares Alves: As ideologias de gênero e de gênesis da "ministra terrivelmente cristã" dos Direitos Humanos. Revista Brasileira de História das Religiões: ANPUH, Ano XII, n. 34, 2019.

(Org.). Política, religião e diversidades: Educação e espaço público (Vol. 1) - $3^{\circ}$ Simpósio Internacional da ABHR / XVI Simpósio Nacional da ABHR. Florianópolis: ABHR / Fogo Editorial, 2018.

(Org.). Política, religião e diversidades: Educação e espaço público (Vol. 2) - $3^{\circ}$ Simpósio Internacional da ABHR / XVI Simpósio Nacional da ABHR. Florianópolis: ABHR / Fogo Editorial, 2020.

. Quando Clio encontra Hermafrodito e Tirésias, mas Narciso está no caminho: Reflexões a partir de história oral em ministérios de "cura" de travestis. Esboços, Florianópolis, v. 23, n. 35, p. 210-228, 2016.

. (Re/des) conectando gênero e religião. Peregrinações e conversões trans* e ex-trans* em narrativas orais e do Facebook. Tese (Doutorado). Programa de Pós-graduação em História Social. Orientação de José Carlos Sebe Bom Meihy. Universidade de São Paulo (USP). São Paulo, 2014.

(Org.). Religião, Direitos Humanos e laicidade: Resistência, diversidades e sensibilidades $-3^{\circ}$ Simpósio Nordeste da ABHR Florianópolis: ABHR / Fogo Editorial, 2019.

(Org.). Religiões e religiosidades em (con)textos (Volume 1). $1^{\circ}$ Simpósio Internacional da ABHR / I Simpósio Sudeste da ABHR. São Paulo: Fonte Editorial, 2013.

(Org.). Religiões e religiosidades em (con)textos (Volume 2). $1^{\circ}$ Simpósio Internacional da ABHR / I Simpósio Sudeste da ABHR. São Paulo: Fonte Editorial, 2014. 
. "Um tapa na cara pra quem diz que cura gay não existe": A ideologia de gênesis em Cleycianne, Lady Gaga e Marco Feliciano. Religare, v.15, n.2, p. 612-651, 2018.

MEZZOMO, Frank Antonio. Deputados evangélicos e o Programa Escola Sem Partido na Assembleia Legislativa do Estado do Paraná. In: MARANHÃO Fo Eduardo Meinberg de Albuquerque (Org.). Política, Religião e Diversidades: Educação e Espaço Público (Vol. 1). Florianópolis: ABHR / Fogo, 2018, p. 378-394.

MOTA, Jorge Cesar. A História Das Religiões no Currículo Da Universidade. In: Revista de História USP, São Paulo, vol. 52, n.103, 1975.

MOURA, Fernanda Pereira de. "Escola Sem Partido": Relações entre Estado, Educação e Religião e os impactos no Ensino de História. Dissertação (Mestrado). Mestrado Profissional em Ensino de História. Orientação de Alessandra Carvalho. Rio de Janeiro: Universidade Federal do Rio de Janeiro (UFRJ). 2016.

NORA, Pierre. Entre memória e história: a problemática dos lugares. Projeto História, S.Paulo, n.10, dez. 1993, p.7-28.

PEDRO, Joana Maria. Os sentimentos do feminismo. In: ERTZOGUE, Marina Haizenreder e PARENTE, Temis Gomes (Orgs.). História e sensibilidade. Brasília: Paralelo 15, 2006.

PROUST, Marcel. Em busca do tempo perdido. Vol. 2. A sombra das raparigas em flor. Rio de Janeiro: Ediouro, 2002.

RIOUX, Jean-Pierre. Pode-se fazer uma história do presente? In: CHAUVEAU, A., TÉTART, P. (orgs.). Questões para a história do presente. Bauru, SP: EDUSC, 1999. p.39-50.

TAVARES, Flávio. Memórias do esquecimento. Rio de Janeiro: Globo, 1999.

TERZETTI FILHO, Celso Luiz. Uma porta para o diálogo: o Simpósio Sudeste e Simpósio Internacional da ABHR. São Paulo: REVER / PUC-SP, Ano 13, No 02, Jul/Dez 2013.

SANTIROCCHI, Ítalo Domingos. Um olhar sobre o XIV Simpósio Nacional da Associação Brasileira de História das Religiões. Reflexão, Campinas, 40(1):119-123, jan./jun., 2015.

SANTOS, João Marcos Leitão (Org). Religião, a herança das crenças e as diversidades de crer. Anais do $1^{\circ}$ Simpósio Sul da Associação Brasileira de História das Religiões (ABHR). Campina Grande, 2013.

SARLO, Beatriz. Tempo passado. Cultura da Memória e Guinada Subjetiva. São Paulo: Companhia das Letras, 2007.

SILVA, Elizete da. A Associação Brasileira de História das Religiões: ultrapassando os limites da sacristia e adentrando a academia. In: MARANHÃO Fo, 
Eduardo Meinberg de Albuquerque. (Org.). Política, religião e diversidades: Educação e espaço público (Vol. 2) - II Simpósio Internacional da ABHR / XVI Simpósio Nacional da ABHR. Florianópolis: ABHR / Fogo Editorial, 2020.

SILVA, Wellington da. A ABHR e os estudos da religião no Brasil. In: BOBSIN, Oneide; SCHAPER, Valério Guilherme; REBLIN, Iuri Andréas. Cartografias do sagrado e do profano: religião, espaço e fronteira (Orgs.). Anais do $1^{\circ}$ Simpósio Sul da Associação Brasileira de História das Religiões (ABHR). São Leopoldo, 2014.

SOUZA, Odair; MARANHÃO Fo ${ }^{o}$ Eduardo Meinberg de Albuquerque. Gênero e Diversidade na Escola ou Ideologia de Gênero? Reações religiosas a um Plano Municipal de Educação de Santa Catarina. Poder e Cultura, v.5, n.9, p. 330-349, 2018.

WOLFF, Cristina Scheibe. Eu só queria embalar meu filho. Gênero e maternidade no discurso dos movimentos de resistência às ditaduras no Cone Sul, América do Sul. Revista Aedos. Vol. 5, n. 13, p. 117-131, 2013.

. Pedaços de alma: emoções e gênero nos discursos da resistência. Revista de Estudos Feministas, Florianópolis, v. 23, n. 3, p. 975-989, nov. 2015. ZDEBSKYI, Janaína de Fátima; PEDRO, Joana Maria; MARANHÃO Fo Eduardo Meinberg de Albuquerque. A histérica e as belas, recatadas e do lar: misoginia à Dilma Rousseff na concepção das mulheres como costelas e dos homens como cabeça da política brasileira. Espaço e Cultura, 38, p. 225-250, 2015.

\section{Internet}

I SIMPÓSIO Centro-Oeste da Associação Brasileira de História das Religiões (ABHR). $\mathbf{O}$ céu, o inferno e além: o pós-morte na História das Religiões. Acesso em: 25 mar. 2020. Disponível em: http://www.simposioreligiao.ueg. br/noticia/48369_i_circular

ASSOCIAÇÃO BRASILEIRA DE HISTÓRIA DAS RELIGIÕES - ABHR. ABHRinha. Acesso em 20 maio 2019. Disponível em: http://www.abhr.org. br/abhr//abhrinha.

ASSOCIAÇÃO BRASILEIRA DE HISTÓRIA DAS RELIGIÕES - ABHR. Atas (datas diversas). Acesso em 20 maio 2019. Disponível em: http://www. abhr.org.br/.

ASSOCIAÇÃO BRASILEIRA DE HISTÓRIA DAS RELIGIÕES - ABHR. Anais do $1^{\circ}$ Simpósio Internacional da ABHR / I Simpósio Sudeste da ABHR. Acesso em 20 maio 2019. Disponível em: /wp-content/uploads/2013/09/Anais-simpósio-da-ABHR-Sudeste.pdf.

ASSOCIAÇÃO BRASILEIRA DE HISTÓRIA DAS RELIGIÕES - ABHR. Caderno de Programação e Resumos do $1^{\circ}$ Simpósio Internacional da ABHR 
/ I Simpósio Sudeste da ABHR. Acesso em 20 maio 2019. Disponível em: http://www.abhr.org.br/publicacoes/anais-dos-simposios/anais-do-i-simposio-regional-sudeste-i-simposio-internacional-da-abhr/caderno-de-programacao-e-resumos-2

ASSOCIAÇÃO BRASILEIRA DE HISTÓRIA DAS RELIGIÕES - ABHR. Campanha Nacional pela Laicidade do Estado - Carta da ABHR pela Laicidade do Estado (28 out. 2018). Acesso em 20 maio 2019. Disponível em: www.abhr.org.br/campanha-nacional-pela-laicidade-do-estado.

ASSOCIAÇÃO BRASILEIRA DE HISTÓRIA DAS RELIGIÕES - ABHR. Cartas Abertas e Moções da ABHR (datas diversas). Acesso em 20 maio 2019. Disponível em: http://www.abhr.org.br/abhr/cartas-da-abhr.

ASSOCIAÇÃO BRASILEIRA DE HISTÓRIA DAS RELIGIÕES - ABHR. Direção Executiva (Gestão 2017-2019). Acesso em 20 maio 2019. Disponível em:https://abhr2018.paginas.ufsc.br/direcao-executiva-da-abhr/

ASSOCIAÇÃO BRASILEIRA DE HISTÓRIA DAS RELIGIÕES - ABHR. Fazendo Arte da ABHR. Acesso em 20 maio 2019. Disponível em: http:// www.abhr.org.br/abhr/fazendo-arte-da-abhr.

ASSOCIAÇÃO BRASILEIRA DE HISTÓRIA DAS RELIGIÕES - ABHR. Filiação de instituições à ABHR. Acesso em 20 maio 2019. Disponível em: https://abhr2018.paginas.ufsc.br/filiacao-de-entidades-a-abhr/.

ASSOCIAÇÃO BRASILEIRA DE HISTÓRIA DAS RELIGIÕES - ABHR. Prêmio ABHR de Fotos (Prêmio Maria Lúcia Montes). Acesso em 20 maio 2019. Disponível em: https://abhr2018.paginas.ufsc.br/premio-abhr-de-fotos/

ASSOCIAÇÃO BRASILEIRA DE HISTÓRIA DAS RELIGIÕES - ABHR. Prêmio ABHR de Pôsteres (Prêmio Sergio Ferretti). Acesso em 20 maio 2019. Disponível em: https://abhr2018.paginas.ufsc.br/premio-abhr-de-posteres/.

ASSOCIAÇÃO BRASILEIRA DE HISTÓRIA DAS RELIGIÕES - $\boldsymbol{A} \boldsymbol{B} \boldsymbol{H} \boldsymbol{R}$. Prêmio ABHR de Teses, Dissertações e TCCs (Prêmio Pierre Sanchis). Acesso em 20 maio 2019. Disponível em: https://abhr2018.paginas.ufsc.br/premio-abhr-de-teses/

A GRANDE Onda vai te pegar. Página do Facebook. Disponível em: <www. facebook.com/A-grande-onda-vai-te-pegar-Marketing-espet-e-ciber-na-Bola-de-Neve-Church-600883706638627/>. Acesso em: 25 out. 2013.

ABHR / ACSRM / ANPUH / GTHRR-ANPUH. Carta Aberta da ABHR sobre a polêmica em torno de "A grande onda vai te pegar. Marketing, espetáculo e ciberespaço na Bola de Neve Church". Co-assinada pelo GTHRR/ANPUH e apoiada pela ACSRM e ANPUH. (5/11/2013). Disponível em: <www.abhr. org.br/abhr/cartas-da-abhr >. Acesso em: 07 nov. 2013. 
ARAGÃO, Gilbraz. Ciências da Religião/UNICAP. Convivência das religiões (notícia 3) (22/11/2013). Disponível em: <http://crunicap.blogspot.com. br/2013/11/convivencia-das-religioes.html >. Acesso em: 25 nov. 2013.

BALLOUSSIER, Anna Virginia. Folha de S. Paulo. Religiosamente. Bola de Neve tenta barrar 'biografia' sobre marketing e igreja (18/11/2013). Disponível em: $<$ http://religiosamente.blogfolha.uol.com.br/2013/11/18/bola-de-neve/>. Acesso em: 18 nov. 2013.

BOLA DE NEVE CHURCH. Ação de fazer e não fazer cumulada c/c indenização com pedido de liminar pelo rito ordinário. 2013. Disponível em: $<$ http://docs.wixstatic.com/ugd/8be452_af73afeb54ae416d95997b888ae76e28. pdf>. Acesso em: 18 nov. 2013.

CARDOSO, Rodrigo. Revista ISTOÉ. O que a bola de neve quer esconder? (20/12/2013). No 2301. Disponível em: <http://istoe.com.br/340567_O+QU $\mathrm{E}+\mathrm{A}+\mathrm{BOLA}+\mathrm{DE}+\mathrm{NEVE}+\mathrm{QUER}+\mathrm{ESCONDER} />$. Acesso em: $25 \mathrm{dez} .2013$.

DIÁRIO de Justiça do Estado de São Paulo. Jusbrasil. Página 420 da Judicial - $2^{\text {a }}$ Instância do Diário de Justiça do Estado de São Paulo (DJSP) de 1 de Novembro de 2013. Disponível em: <https://www.jusbrasil.com.br/ diarios/61173594/djsp-judicial-2a-instancia-01-11-2013-pg-420>. Acesso em: 03 nov. 2013.

FERNANDES, Danilo. Blog do Genizah. A bola fora da advogada da Bola de Neve e do Apóstolo Rina. (22/04/2014). Disponível em: $<w w w . g e-$ nizahvirtual.com/2014/07/exclusivo-bola-fora-da-advogada-da.html $>$. Acesso em: 22 abril 2014.

. Blog do Genizah. Bola de Neve toma caixote épico nas páginas da Revista Hardcore (28/09/2013). <www.genizahvirtual.com/2013/09/ bola-de-neve-toma-caixote-epico-nas.html>. Acesso em: 03 jan. 2014.

. Blog do Genizah. Censura, truculência e ameaças. Bola de Neve mostra a sua cara novamente. Disponível em: <www.genizahvirtual. com/2013/11/censura-truculencia-e-ameacas-bola-de.html $>$.

. Blog do Genizah. Revista IstoÉ expõe negócio do Apóstolo Rina: O que a bola de neve quer esconder? (02/01/2014). Disponível em: $<$ www.genizahvirtual.com/2014/01/revista-istoe-expoe-negocio-do-apostolo. html>. Acesso em: 03 jan. 2014.

GOUVEIA, Ricardo Quadros. Ultimato. Os 12 livros de 2013 que os cristãos devem ler. (16/12/2013). Disponível em: <www.ultimato.com.br/conteudo/ os-12-livros-de-2013-que-os-cristaos-devem-ler>. Acesso em: 25 dez. 2013.

HARTMANN, Ivar A. M. Supremo Tribunal Federal (STF). Menção à Grande Onda em audiência do STF sobre as biografias não-autorizadas. (21/11/2013). Disponível em: <http://www.youtube.com/watch? $\mathrm{v}=$ PRav$-\mathrm{I} 6 \mathrm{RVOM} \&$ feature $=\mathrm{c} 4$-overview\&list $=\mathrm{UUsW} 4 \mathrm{QSB} 1 \mathrm{USsu} 9$ ouu FU We4Iw $>$. . Acesso em: 23 nov. 2013. 
HUFF JUNIOR, Arnaldo. Simpósio nacional sobre religiões está com inscrição aberta (18 de maio de 2011). Acesso em: 20 mar. 2020. Disponível em: http://www.ufjf.br/arquivodenoticias/2011/05/universidade-sediara-simposio-nacional-sobre-religioes/

MARANHÃO $F^{o}$, Eduardo Meinberg de Albuquerque. Seria o início de uma "mordaça evangélica"? (4/12/2013). Brasil 247. Disponível em: $<$ www.brasil247.com/pt/247/artigos/122910/Seria-o-in\%C3\%ADcio-de-uma-'morda\%C3\%A7a-evang\%C3\%A9lica'.htm>. Acesso em: 04 dez. 2013.

REVISTA DA ESPM. Inversão de valores. Entrevista com Eduardo Meinberg de Albuquerque Maranhão Fo. N.1, p. 52-56, janeiro de 2014. Disponível em: $<$ http://bibliotecasp.espm.br/index.php/espm/issue/view/95/showToc $>$. Acesso em: 10 mar. 2013.

SIQUEIRA, Paulo. Pedras que Clamam. Igreja Bola de Neve tenta impedir lançamento de livro: será a tal perseguição religiosa profetizada nas Escrituras? (08/11/2013). Disponível em: <https://pedrasclamam.wordpress. com/2013/11/08/igreja-bola-de-neve-tenta-impedir-lancamento-e-venda-de-livro-sera-a-tal-perseguicao-religiosa-profetizada-nas-escrituras/ $>$. Acesso em: 08 nov. 2013.

SIQUEIRA, Vera. Uma Estrangeira no Mundo. Igreja Bola de Neve tenta impedir lançamento de livro: será a tal perseguição religiosa profetizada nas Escrituras? (08/11/2013). Disponível em: <https://estrangeira.wordpress. com/2013/11/08/igreja-bola-de-neve-tenta-impedir-lancamento-e-venda-de-livro-sera-a-tal-perseguicao-religiosa-profetizada-nas-escrituras/>. Acesso em: 08 nov. 2013.

ZANVETTOR, Rafael. Caros Amigos. Igreja Bola de Neve tenta barrar livro de historiador (02/12/2013). Disponível em: <www.carosamigos.com. br/index.php/cotidiano/1900-igreja-bola-de-neve-tenta-barrar-livro-de-historiador>. Acesso em: 03 dez. 2013.

\section{Vídeos}

Posição da Associação Brasileira de História das Religiões (ABHR) contra o golpe. Acesso em: 29 maio 2016. Disponível em: https://www.youtube.com/ watch? $\mathrm{v}=$ GtyecGzppSc\&t=49s

CANAL DA ABHR. Misoginia no Golpe de 2016 - Marlene de Fáveri e Du Meinberg Maranhão - ABHR Sul de 2017. (21 jun. 2018). Acesso em: 25 jun. 2018. Disponível em: https://www.youtube.com/watch? $v=6 i U H J b k l H B o \& t=36 \mathrm{~s}$

\section{Filme}

GANSEL, Dennis. A Onda (Die Welle). Alemanha, 1988. 107 min. 